\title{
Structural Characterization of
}

\section{Monohydroxyeicosatetraenoic Acids and Dihydroxy- and Trihydroxyeicosatrienoic Acids by ESI-FTICR}

\author{
Lijie Cui, ${ }^{\text {a }}$ Marilyn A. Isbell, ${ }^{a}$ Yuttana Chawengsub, ${ }^{a}$ John R. Falck, ${ }^{b}$ \\ William B. Campbell, a and Kasem Nithipatikom ${ }^{a}$ \\ ${ }^{a}$ Department of Pharmacology and Toxicology, Medical College of Wisconsin, Milwaukee, Wisconsin, USA \\ ${ }^{b}$ Departments of Biochemistry and Pharmacology, University of Texas Southwestern Medical Center, Dallas, \\ Texas, USA
}

The fragmentation characteristics of monohydroxyeicosatetraenoic acids and dihydroxy- and trihydroxyeicosatrienoic acids were investigated by electrospray ionization Fourier transform ion cyclotron resonance (FTICR) mass spectrometry using sustained off-resonance irradiation collision-induced dissociation (SORI-CID) and infrared multiphoton dissociation (IRMPD). The fragmentation patterns of these compounds were associated with the number and positions of the hydroxyl substituents. The fragmentation is more complicated with increasing number of the hydroxyl groups of the compounds. In general, the major carbon-carbon cleavage of $[\mathrm{M}-\mathrm{H}]^{-}$ions occurred at the $\alpha$-position to the hydroxyl group, and the carbon-carbon cleavage occurred when there was a double-bond at the $\beta$-position to the hydroxyl group. SORI-CID and IRMPD produced some common fragmentation patterns; however, each technique provided some unique patterns that are useful for structural identification of these compounds. This study demonstrated the application of FTICR via the identification of regioisomers of trihydroxyeicosatrienoic acids in rabbit aorta samples. (J Am Soc Mass Spectrom 2008, 19, 569-585) @ 2008 American Society for Mass Spectrometry

$\mathrm{M}$ ass spectrometry has emerged as an important tool for analysis of biomolecules. Fourier transform ion cyclotron resonance (FTICR) mass spectrometry is one of the techniques that can provide high mass accuracy and high mass resolution [1-6]. Accurate molecular weight, elemental composition, and structural information can be achieved from FTICR. Sustained off-resonance irradiation collisioninduced dissociation (SORI-CID) and infrared multiphoton dissociation (IRMPD) are two different dissociation techniques often used with FTICR for MS/MS analysis. SORI-CID involves collision of the target ion slightly off its resonance frequency with a collision gas, causing the acceleration and deceleration of ions during the RF pulse. At a frequency of several kilohertz, multiple low-energy collisions occur as ions are vibrationally excited for a sustained period. Unlike SORICID, no collision gas is required for IRMPD. Instead, the $75 \mathrm{~W} \mathrm{CO}$ laser is used to irradiate the ions to form fragments. The fragments may continue to acquire some energy from the infrared laser pulse and further fragment to ions of lower masses. This study demon-

Address reprint requests to Dr. Kasem Nithipatikom, Department of Pharmacology and Toxicology, Medical College of Wisconsin, 8701 Watertown Plank Road, Milwaukee, Wisconsin 53226, USA. E-mail: kasemn@ mcw.edu strates the utility of SORI-CID and IRMPD for the structural characterization of monohydroxyeicosatetraenoic acids (HETEs) and dihydroxy- and trihydroxyeicosatrienoic acids (DHETs and THETAs).

HETEs, DHETs, and THETAs are metabolites of arachidonic acid (AA). Different isoforms of lipoxygenases (LOX) metabolize AA to regioisomeric HETEs. 12-Hydroxy-5,8,10,14-eicosatetraenoic acid (12-HETE) and 15-HETE are important lipid mediators in inflammation, kidney, immune system, prostate diseases, and diabetes [7-14]. Cytochrome P450 epoxygenases metabolize AA to 4 regioisomeric epoxyeicosatrienoic acids (EETs), and soluble epoxide hydrolase (sEH) enzymes subsequently convert EETs to the corresponding DHETs [15-17]. EETs have various biological functions, including inhibiting the hydro-osmotic action of arginine vasopressin in the kidney, calcium mobilization, and prostaglandin formation [18, 19]. EETs stimulate relaxation in coronary rings and coronary arterioles [20-25]. A recent study showed that 14,15-DHET is a potent peroxisome proliferator-activated receptor- $\alpha$ $(\operatorname{PPAR} \alpha)$ activator in COS-7 cells [26].

THETAs are new members of the family of endothelium-derived relaxing factors [27-31]. 11,12,15THETA and 11,14,15-THETA were identified as endothelium-derived lipoxygenase metabolites of AA in
(C) 2008 American Society for Mass Spectrometry. Published by Elsevier Inc. $1044-0305 / 08 / \$ 32.00$

doi:10.1016/j.jasms.2008.01.007
Published online January 31, 2008 Received August 21, 2007 Revised January 17, 2008 Accepted January 17, 2008 
the rabbit aorta. Recent studies have shown that THETAs relax rabbit small mesenteric arteries [31]. 11,12,15THETA mediates acetylcholine-induced relaxations by activating apamin-sensitive potassium $\left(\mathrm{K}^{+}\right)$channels in vascular smooth muscle to induce $\mathrm{K}^{+}$efflux, membrane hyperpolarization, and vascular relaxation [27, 28], while $11,14,15$-THETA is not vasoactive $[28,29]$. These studies cogently indicate that biological function is dependent upon the position of the hydroxyl groups.

Previous studies showed that HETEs and DHETs form characteristic fragments during $\mathrm{MS}^{2}$ analysis by ion trap and triple quadrupole mass spectrometers [32-40]. The mechanisms for electrospray ionization and tandem mass spectrometry of various classes of eicosanoids have been elegantly reviewed [41]. In this study, we investigated the mass spectrometric characteristics of HETEs, DHETs, and THETAs by ESI-FTICR using SORI-CID and IRMPD. The effects of the number and the positions of the hydroxyl substituents on fragmentation patterns were characterized, and the identities of THETAs in biological samples were determined.

\section{Experimental}

\section{Materials and Methods}

11-, 12-, and 15-HETE; 11,12- and 14,15-DHET; 14,15EET, and arachidonoyl dopamine were purchased from Cayman Chemical Co. (Ann Arbor, MI). 11,12,15-, $11,14,15-$, and 13,14,15-THETA were synthesized in the laboratory of Dr. J. R. Falck [42]. Indomethacin, A23187, and L-ascorbic acid were purchased from Sigma (St. Louis, MO). $\mathrm{C}_{18}$ Bond Elut solid-phase extraction (SPE) columns were purchased from Varian (Harbor City,
CA). Acetonitrile was HPLC grade. Distilled, deionized water was used in all experiments.

\section{Biological Sample Preparation}

Tissue preparation and incubation. Aortas were isolated from 1- to 2-week old New Zealand White rabbits (Kuiper Rabbit Ranch, Gary, IN), placed in ice-cold HEPES buffer (in mM; 10 HEPES, $150 \mathrm{NaCl}, 5 \mathrm{KCl}, 2$ $\mathrm{CaCl}_{2}, 1 \mathrm{MgCl}_{2}$, and 6 glucose; $\mathrm{pH} 7.4$ ), cleaned of adhering connective tissue and fat, and cut into rings (5-mm long). Aortic rings were incubated for $10 \mathrm{~min}$ at $37^{\circ} \mathrm{C}$ in HEPES buffer containing indomethacin $\left(10^{-5} \mathrm{M}\right)$. AA $\left(10^{-4} \mathrm{M}\right)$ was added, and the vessels were incubated for an additional $5 \mathrm{~min}$. Calcium ionophore A23187 (2 $\times$ $10^{-5} \mathrm{M}$ ) was added, and the vessels were incubated for another $15 \mathrm{~min}$. The reaction was stopped by the addition of ethanol to a final concentration of $15 \%$. The incubation buffer was removed, acidified $(\mathrm{pH}<3.5)$ with glacial acetic acid, and extracted on Bond Elut C-18 extraction columns as previously described [27-29]. The extracts were evaporated to dryness under a stream of $\mathrm{N}_{2}$ and stored at $-40^{\circ} \mathrm{C}$ until further HPLC separation.

Separation of AA metabolites by HPLC. The extracted samples were first separated into fractions of metabolite groups by reverse-phase HPLC (Nucleosil-C18 column, $5 \mu \mathrm{m}, 4.6 \times 250 \mathrm{~mm}$ ) using water:acetonitrile mobile phase containing $0.1 \%$ glacial acetic acid. The program was a 40 -min linear gradient from $50 \%$ acetonitrile in water to $100 \%$ acetonitrile [28]. The fractions $(0.2 \mathrm{~mL}$ per fraction) corresponding to the THETAs (fractions 27-35; 5-7.5 $\mathrm{min}$ ) were collected and extracted with

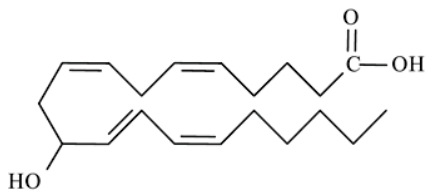

11-HETE

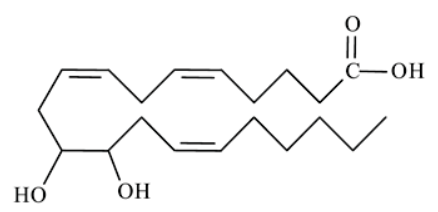

11,12-DHET

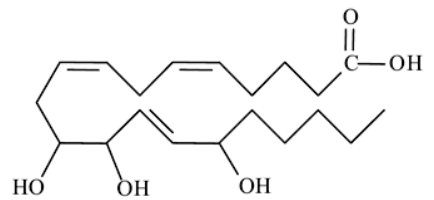

11,12,15-THETA

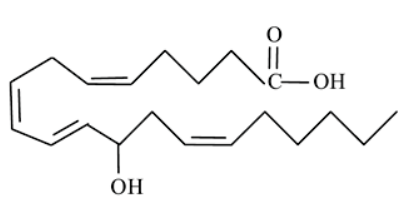

12-HETE

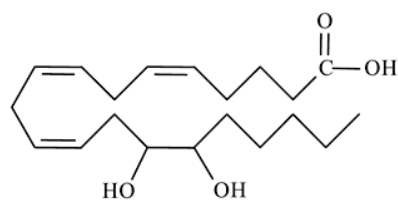

14,15-DHET

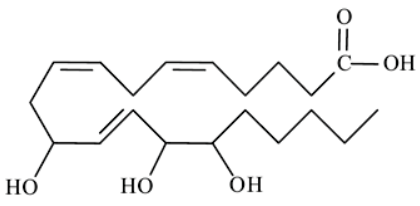

11,14,15-THETA

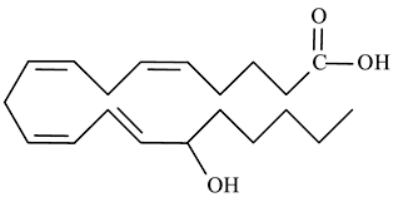

15-HETE

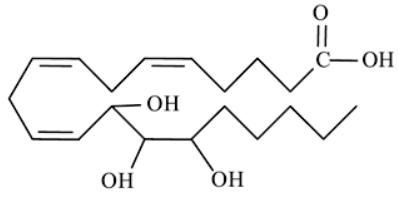

13,14,15-THETA

Figure 1. Structures of HETEs (11-HETE, 12-HETE and 15-HETE), DHETs (11,12-DHET and 14,15-DHET), and THETAs (11,12,15-THETA, 11,14,15-THETA and 13,14,15-THETA). 
50:50 cyclohexane:ethyl acetate. The extract was dried under a stream of $\mathrm{N}_{2}$ and redissolved in the HPLC mobile phase. The THETA fraction was rechromatographed on reverse-phase HPLC using water:acetonitrile (containing $0.1 \%$ glacial acetic acid) mobile phase. The program consisted of a 5-min isocratic phase with 35\% acetonitrile in water, followed by a 35-min linear gradient to $85 \%$ acetonitrile [28]. The fractions that contained the THETAs (fractions 87-93; 17.5-18.5 min) were collected, acidified with acetic acid, and extracted with a 50:50 cyclohexane:ethyl acetate. The samples were dried under a stream of $\mathrm{N}_{2}$ and analyzed by LC-FTICR.

\section{Fourier Transform Ion Cyclotron Resonance Mass Spectrometry}

For the standards, the experiments were performed on a 7.0 tesla FTICR (IonSpec, Lake Forest, CA) with a
Z-spray ESI source (Waters Corporation, Milford, MA) and a Model 22 syringe pump (Harvard, Holliston, MA) or a high-performance liquid chromatograph (HPLC, Agilent 1100 series, Palo Alto, CA). Standards were diluted in 50\% acetonitrile:water solution. The standards were either directly infused by the syringe pump at a rate of $3 \mu \mathrm{L} / \mathrm{min}$ or introduced by flow injection (1 $\mu \mathrm{L}$ ) through HPLC (Agilent 1100 series, Palo Alto, CA) into the electrospray source. FTICR was externally calibrated using 14,15-EET, L-ascorbic acid, and arachidonoyl dopamine. Although FTICR can detect HETEs and DHETs at $5 \mathrm{pg}$ and THETAs at $15 \mathrm{pg}$, the MS/MS spectra were measured with HETEs and DHETs at 100 pg and THETAs at $500 \mathrm{pg}$. These concentrations were used to assure that the low abundant ions have adequate signals and they were accurately measured. Mass spectra were acquired in negative mode with ESI probe and source temperature of $80^{\circ} \mathrm{C}$. The sample cone
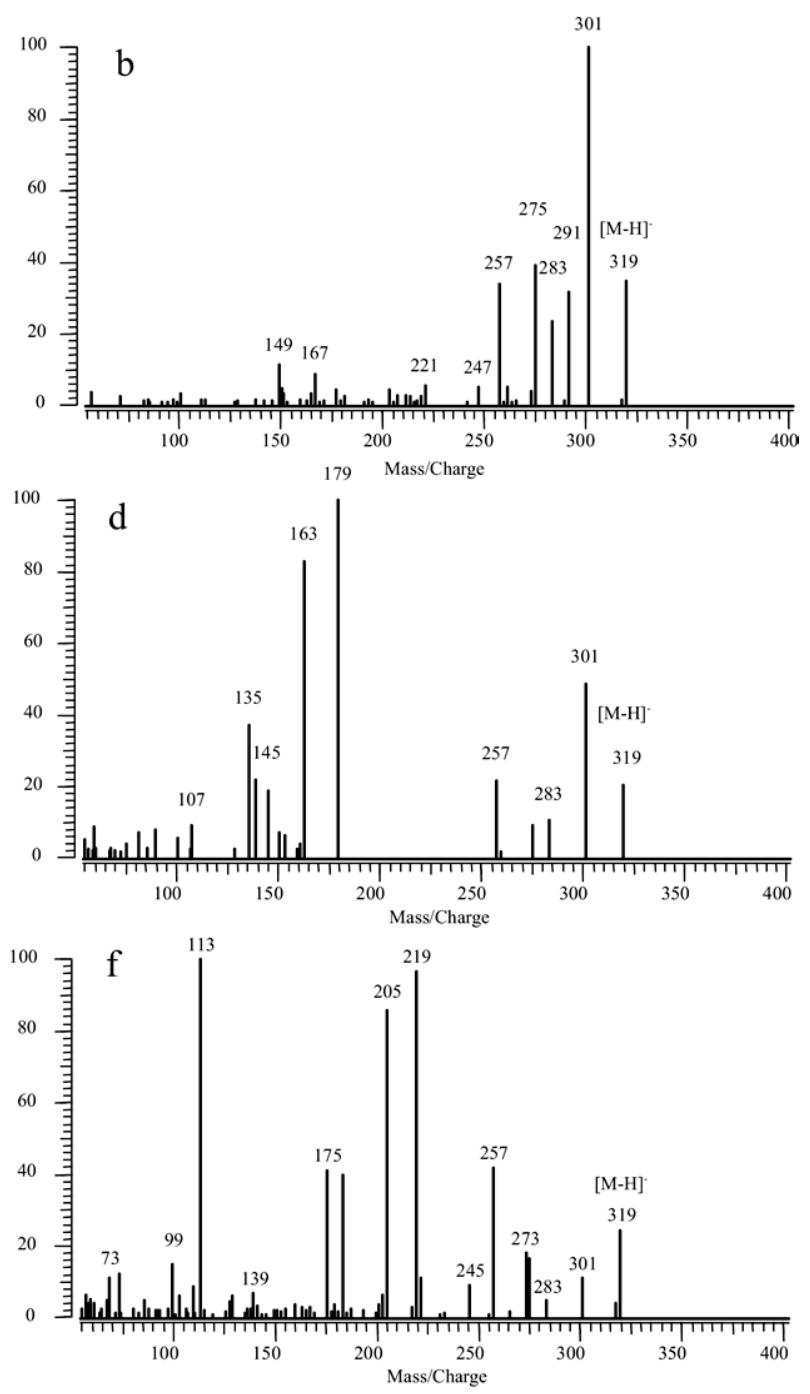

Figure 2. MS/MS spectra of $[\mathrm{M}-\mathrm{H}]^{-}, \mathrm{m} / \mathrm{z} 319$ for HETEs (100 pg) obtained from negative ion ESI SORI-CID and IRMPD FTICR. (a) MS/MS spectrum of 11-HETE by SORI-CID; (b) MS/MS spectrum of 11-HETE by IRMPD; (c) MS/MS spectrum of 12-HETE by SORI-CID; (d) MS/MS spectrum of 12-HETE by IRMPD; (e) MS/MS spectrum of 15-HETE by SORI-CID; (f) MS/MS spectrum of 15-HETE by IRMPD. 
Table 1. High-resolution accurate mass measurements by SORI-CID FTICR for HETEs

\begin{tabular}{ccccc}
\hline Measured ions $(\mathrm{m} / \mathrm{z})$ & Calculated ions $(\mathrm{m} / \mathrm{z})$ & Error $(\mathrm{ppm})$ & Relative abundance $(\%)$ & Elemental composition \\
\hline \hline 11-HETE & & & & \\
319.22872 & 319.22787 & 2.7 & 17.83 & $\mathrm{C}_{20} \mathrm{H}_{31} \mathrm{O}_{3}{ }^{-1}$ \\
301.21788 & 301.21730 & 1.9 & 77.16 & $\mathrm{C}_{20} \mathrm{H}_{29} \mathrm{O}_{2}{ }^{-1}$ \\
275.23886 & 275.23804 & 3.0 & 42.94 & $\mathrm{C}_{19} \mathrm{H}_{31} \mathrm{O}^{-1}$ \\
257.22796 & 257.22747 & 1.9 & 100.00 & $\mathrm{C}_{19} \mathrm{H}_{29}{ }^{-1}$ \\
207.17625 & 207.17544 & 3.9 & 4.95 & $\mathrm{C}_{14} \mathrm{H}_{23} \mathrm{O}^{-1}$ \\
167.10801 & 167.10775 & 1.6 & 52.71 & $\mathrm{C}_{10} \mathrm{H}_{15} \mathrm{O}_{2}{ }^{-1}$ \\
149.09752 & 149.09719 & 2.2 & 22.75 & $\mathrm{C}_{10} \mathrm{H}_{13} \mathrm{O}^{-1}$ \\
123.11851 & 123.11792 & 4.8 & 6.43 & $\mathrm{C}_{9} \mathrm{H}_{15}{ }^{-1}$ \\
$12-\mathrm{HETE}$ & & & & \\
319.22722 & 319.22787 & -2.0 & 23.16 & $\mathrm{C}_{20} \mathrm{H}_{31} \mathrm{O}_{3}{ }^{-1}$ \\
301.21653 & 301.21730 & -2.6 & 26.61 & $\mathrm{C}_{20} \mathrm{H}_{29} \mathrm{O}_{2}^{-1}$ \\
257.22674 & 257.22747 & -2.8 & 100.00 & $\mathrm{C}_{19} \mathrm{H}_{29}^{-1}$ \\
179.10724 & 179.10775 & -2.8 & 48.37 & $\mathrm{C}_{11} \mathrm{H}_{15} \mathrm{O}_{2}^{-1}$ \\
163.11239 & 163.11284 & -2.8 & 43.48 & $\mathrm{C}_{11}^{-1} \mathrm{H}_{15} \mathrm{O}^{-1}$ \\
135.11756 & 135.11792 & -2.7 & 63.85 & $\mathrm{C}_{10} \mathrm{H}_{15}{ }^{-1}$ \\
$15-\mathrm{HETE}$ & & & & \\
319.22738 & 319.22787 & -1.5 & 42.76 & $\mathrm{C}_{20} \mathrm{H}_{31} \mathrm{O}_{3}^{-1}$ \\
301.21563 & 301.21730 & -5.5 & 17.34 & $\mathrm{C}_{20}^{-1} \mathrm{H}_{29} \mathrm{O}_{2}{ }^{-1}$ \\
257.22673 & 257.22747 & -2.9 & 100.00 & $\mathrm{C}_{19} \mathrm{H}_{29}{ }^{-1}$ \\
219.13863 & 219.13905 & -1.9 & 15.96 & $\mathrm{C}_{14} \mathrm{H}_{19} \mathrm{O}_{2}{ }^{-1}$ \\
175.14887 & 175.14922 & -2.0 & 48.96 & $\mathrm{C}_{13} \mathrm{H}_{19}{ }^{-1}$ \\
113.09705 & 113.09719 & -1.2 & 20.82 & $\mathrm{C}_{7} \mathrm{H}_{13} \mathrm{O}^{-1}$ \\
\hline
\end{tabular}

voltage was $-45 \mathrm{~V}$, the extractor cone was $10 \mathrm{~V}, \mathrm{Q} 1 / \mathrm{Q} 2$ RF was $70 \mathrm{~V}$, and arbitrary waveform amplitude was $125 \mathrm{~V}$. The probe high voltage was $3500 \mathrm{~V}$. Transient signals were collected with $1024 \mathrm{~K}$ data points, an analog-to-digital converter (ADC) rate of $4 \mathrm{MHz}$, and the transient length of $65.5 \mathrm{~ms}$. The detection range was set at $m / z$ 54-500. Nitrogen was used as the collision gas and cooling gas. The precursor ions were isolated in
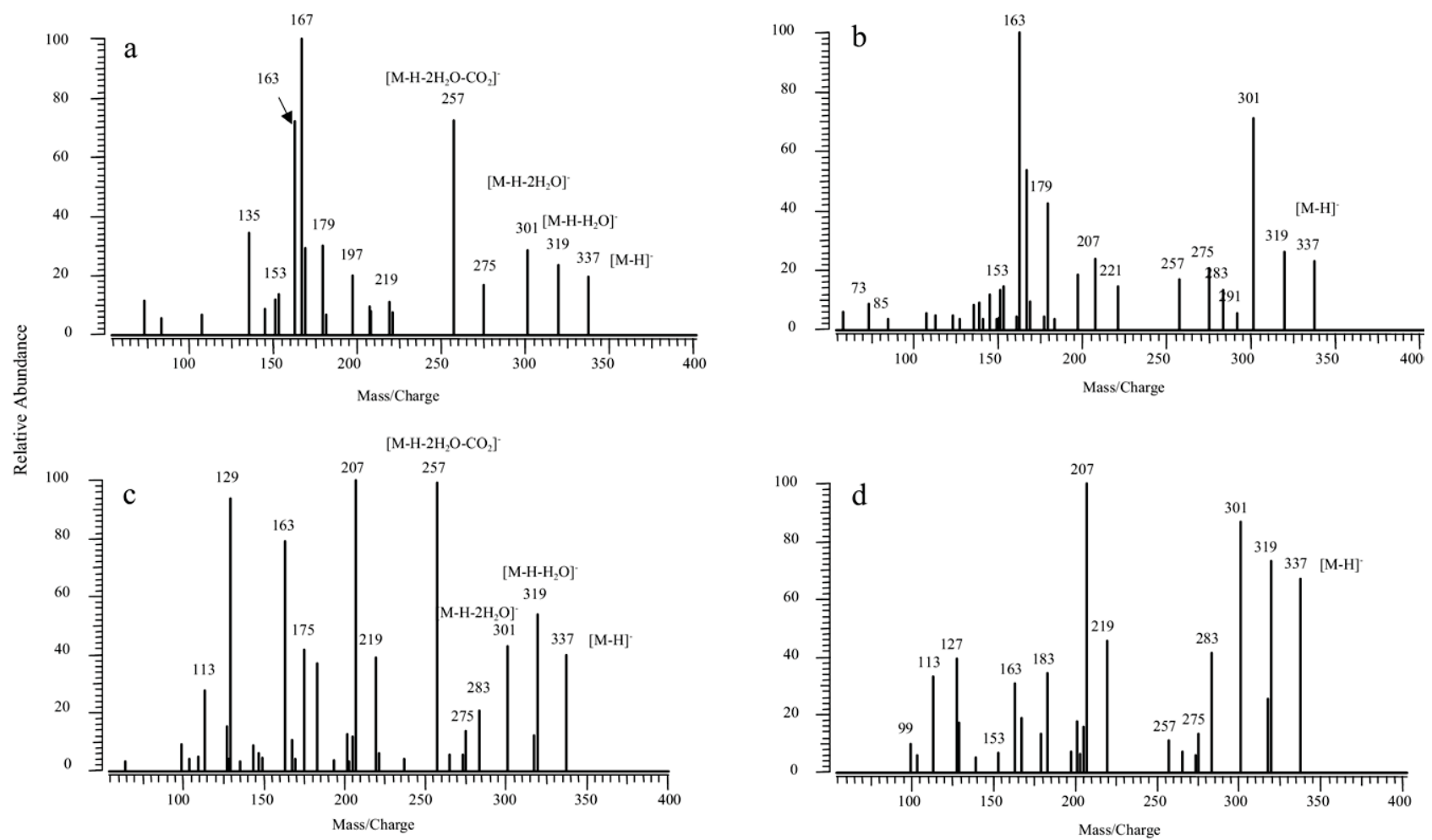

Figure 3. MS/MS spectra of $\left[\mathrm{M}-\mathrm{H}^{-}, \mathrm{m} / \mathrm{z} 337\right.$ for DHETs obtained from negative ion ESI SORI-CID and IRMPD FTICR. (a) MS/MS spectrum of 11,12-DHET by SORI-CID; (b) MS/MS spectrum of 11,12-DHET by IRMPD; (c) MS/MS spectrum of 14,15-DHET by SORI-CID; (d) MS/MS spectrum of 14,15-DHET by IRMPD. 
the ICR cell and dissociated by SORI-CID or IRMPD. SORI-CID was initiated by opening a pulsed valve to admit a SORI burst with a length of $300 \mathrm{~ms}$, offset frequency of $4563 \mathrm{~Hz}$, amplitude of $15.5 \mathrm{~V}$, and gas pulse of $15 \mathrm{~ms}$. IRMPD was conducted with a $75 \mathrm{~W}$ continuous wave $\mathrm{CO}_{2}$ laser at $95 \%$ power pulse, length of $300 \mathrm{~ms}$, and gas pulse of $5 \mathrm{~ms}$. Omega (version 8.0.201, IonSpec) software was used to control the instrument and analyze the data.

\section{LC-FTICR Analysis of THETAs}

LC-FTICR was performed with a 7.0 tesla FTICR coupled to an Agilent 1100 series liquid chromatograph. Both THETA standards and THETA fractions were analyzed by LC-FTICR. The THETA standards were diluted in acetonitrile (1000 pg/ $\mu \mathrm{L})$, and the THETA sample fraction was dissolved in $50 \mu \mathrm{L}$ of acetonitrile. All HPLC separations were performed at ambient temperature. The samples were analyzed on a reversephase $\mathrm{C}_{18}$ column (Kromasil $1.0 \times 150 \mathrm{~mm} 5 \mu \mathrm{m}$; Varian) using water:acetonitrile containing $0.005 \%$ acetic acid as a mobile phase at a flow rate of $100 \mu \mathrm{L} / \mathrm{min}$. The injection volume was $1 \mu \mathrm{L}$. The mobile phase gradient started at $20 \%$ acetonitrile in water, and linearly increased to $44 \%$ acetonitrile over $40 \mathrm{~min}$, and then linear increased to $100 \%$ in $5 \mathrm{~min}$. After $25 \mathrm{~min}$ of run time on the LC, the FTICR was turned on to acquire data. The FTICR conditions were the same as described above for the standards.

\section{Results and Discussion}

The structures of three HETEs, two DHETs, and three THETAs are shown in Figure 1. Mass spectra of these eicosanoids exhibited carboxylate molecular ions [M $\mathrm{H}^{-}$with $m / z 319$ for HETEs, $m / z 337$ for DHETs, and $m / z$ 353 for THETAs as the most abundant ions. For MS/MS experiments, the molecular ions were isolated, accelerated toward the ICR cell, and dissociated. Some similar fragmentation patterns of HETEs, DHETs, and THETAs were observed, indicating the common backbone structures among these compounds. However, there were unique fragmentations reflecting the structural characteristics that can be used to identify these compounds.

\section{Common Fragmentation Pathways for HETEs, DHETs, and THETAs}

MS/MS spectra of all compounds indicated losses of $\mathrm{H}_{2} \mathrm{O}$ and $\mathrm{CO}_{2}$ to form a series of ions. For HETEs (Figure 2 and Table 1), which consist of one hydroxyl group, $m / z 301$ corresponding to $\left[\mathrm{M}-\mathrm{H}-\mathrm{H}_{2} \mathrm{O}\right]^{-}$, was observed in all SORI-CID and IRMPD spectra. The $\mathrm{m} / \mathrm{z}$ 257 was formed by a loss of $\mathrm{CO}_{2}$ from $\left[\mathrm{M}-\mathrm{H}-\mathrm{H}_{2} \mathrm{O}\right]^{-}$. DHETs with two hydroxyl groups, as shown in Figure 3 and Table 2, the molecular ions $(\mathrm{m} / \mathrm{z} 337)$ lost two $\mathrm{H}_{2} \mathrm{O}$ molecules one after another, to form $\mathrm{m} / \mathrm{z} 319$ and 301, assigned as $\left[\mathrm{M}-\mathrm{H}-\mathrm{H}_{2} \mathrm{O}\right]^{-}$and $\left[-\mathrm{H}-2 \mathrm{H}_{2} \mathrm{O}\right]^{-}$, respectively. These ions could further lose $\mathrm{CO}_{2}$ to form $\left[\mathrm{M}-\mathrm{H}-\mathrm{H}_{2} \mathrm{O}-\mathrm{CO}_{2}\right]^{-}(\mathrm{m} / \mathrm{z} 275)$ and $[\mathrm{M}-\mathrm{H}-$ $\left.2 \mathrm{H}_{2} \mathrm{O}-\mathrm{CO}_{2}\right]^{-}(m / z 257)$, respectively. The loss of $\mathrm{H}_{2} \mathrm{O}$ and $\mathrm{CO}_{2}$ are the major fragmentation pathways for

Table 2. High-resolution accurate mass measurements by SORI-CID FTICR for DHETs

\begin{tabular}{|c|c|c|c|c|}
\hline Measured ions $(\mathrm{m} / \mathrm{z})$ & Calculated ions $(\mathrm{m} / \mathrm{z})$ & Error (ppm) & Relative abundance (\%) & Elemental composition \\
\hline \multicolumn{5}{|l|}{ 11.12-DHET } \\
\hline 337.23729 & 337.23843 & -3.4 & 20.04 & $\mathrm{C}_{20} \mathrm{H}_{33} \mathrm{O}_{4}^{-1}$ \\
\hline 319.22748 & 319.22787 & -1.2 & 22.90 & $\mathrm{C}_{20} \mathrm{H}_{31} \mathrm{O}_{3}{ }^{-1}$ \\
\hline 301.21718 & 301.21730 & -0.4 & 27.63 & $\mathrm{C}_{20} \mathrm{H}_{29} \mathrm{O}_{2}^{-1}$ \\
\hline 275.23789 & 275.23804 & -0.5 & 15.95 & $\mathrm{C}_{19} \mathrm{H}_{31} \mathrm{O}^{-1}$ \\
\hline 257.22634 & 257.22747 & -4.4 & 70.41 & $\mathrm{C}_{19} \mathrm{H}_{29}{ }^{-1}$ \\
\hline 207.17419 & 207.17544 & -6.0 & 9.09 & $\mathrm{C}_{14} \mathrm{H}_{23} \mathrm{O}^{-1}$ \\
\hline 197.11742 & 197.11832 & -4.6 & 19.08 & $\mathrm{C}_{11} \mathrm{H}_{17} \mathrm{O}_{3}^{-1}$ \\
\hline 179.10725 & 179.10775 & -2.8 & 30.77 & $\mathrm{C}_{11} \mathrm{H}_{15} \mathrm{O}_{2}^{-1}$ \\
\hline 169.12278 & 169.12340 & -3.7 & 28.75 & $\mathrm{C}_{10} \mathrm{H}_{17} \mathrm{O}_{2}^{-1}$ \\
\hline 167.10714 & 167.10775 & -3.7 & 100.00 & $\mathrm{C}_{10} \mathrm{H}_{15} \mathrm{O}_{2}^{-1}$ \\
\hline 163.11235 & 163.11284 & -3.0 & 75.87 & $\mathrm{C}_{11} \mathrm{H}_{15} \mathrm{O}^{-1}$ \\
\hline 135.11769 & 135.11792 & -1.7 & 36.80 & $\mathrm{C}_{10} \mathrm{H}_{15}^{-1}$ \\
\hline \multicolumn{5}{|l|}{ 14, 15-DHET } \\
\hline 337.23868 & 337.23843 & 0.7 & 38.89 & $\mathrm{C}_{20} \mathrm{H}_{33} \mathrm{O}_{4}^{-1}$ \\
\hline 319.22762 & 319.22787 & -0.8 & 54.05 & $\mathrm{C}_{20} \mathrm{H}_{31} \mathrm{O}_{3}^{-1}$ \\
\hline 301.21849 & 301.21730 & 4.0 & 42.51 & $\mathrm{C}_{20} \mathrm{H}_{29} \mathrm{O}_{2}^{-1}$ \\
\hline 275.23750 & 275.23804 & -2.0 & 19.18 & $\mathrm{C}_{19} \mathrm{H}_{31} \mathrm{O}^{-1}$ \\
\hline 257.22729 & 257.22747 & -0.7 & 98.43 & $\mathrm{C}_{19} \mathrm{H}_{29}{ }^{-1}$ \\
\hline 219.13885 & 219.13905 & -0.9 & 38.19 & $\mathrm{C}_{14} \mathrm{H}_{19} \mathrm{O}_{2}^{-1}$ \\
\hline 207.13931 & 207.13905 & 1.3 & 100.00 & $\mathrm{C}_{13} \mathrm{H}_{19} \mathrm{O}_{2}^{-1}$ \\
\hline 175.14975 & 175.14922 & 3.0 & 40.49 & $\mathrm{C}_{13} \mathrm{H}_{19}{ }^{-1}$ \\
\hline 167.10810 & 167.10775 & 2.1 & 8.12 & $\mathrm{C}_{10} \mathrm{H}_{15} \mathrm{O}_{2}^{-1}$ \\
\hline 163.14947 & 163.14922 & 1.5 & 76.78 & $\mathrm{C}_{12} \mathrm{H}_{19}{ }^{-1}$ \\
\hline 129.09250 & 129.09210 & 3.1 & 92.71 & $\mathrm{C}_{7} \mathrm{H}_{13} \mathrm{O}_{2}^{-1}$ \\
\hline
\end{tabular}



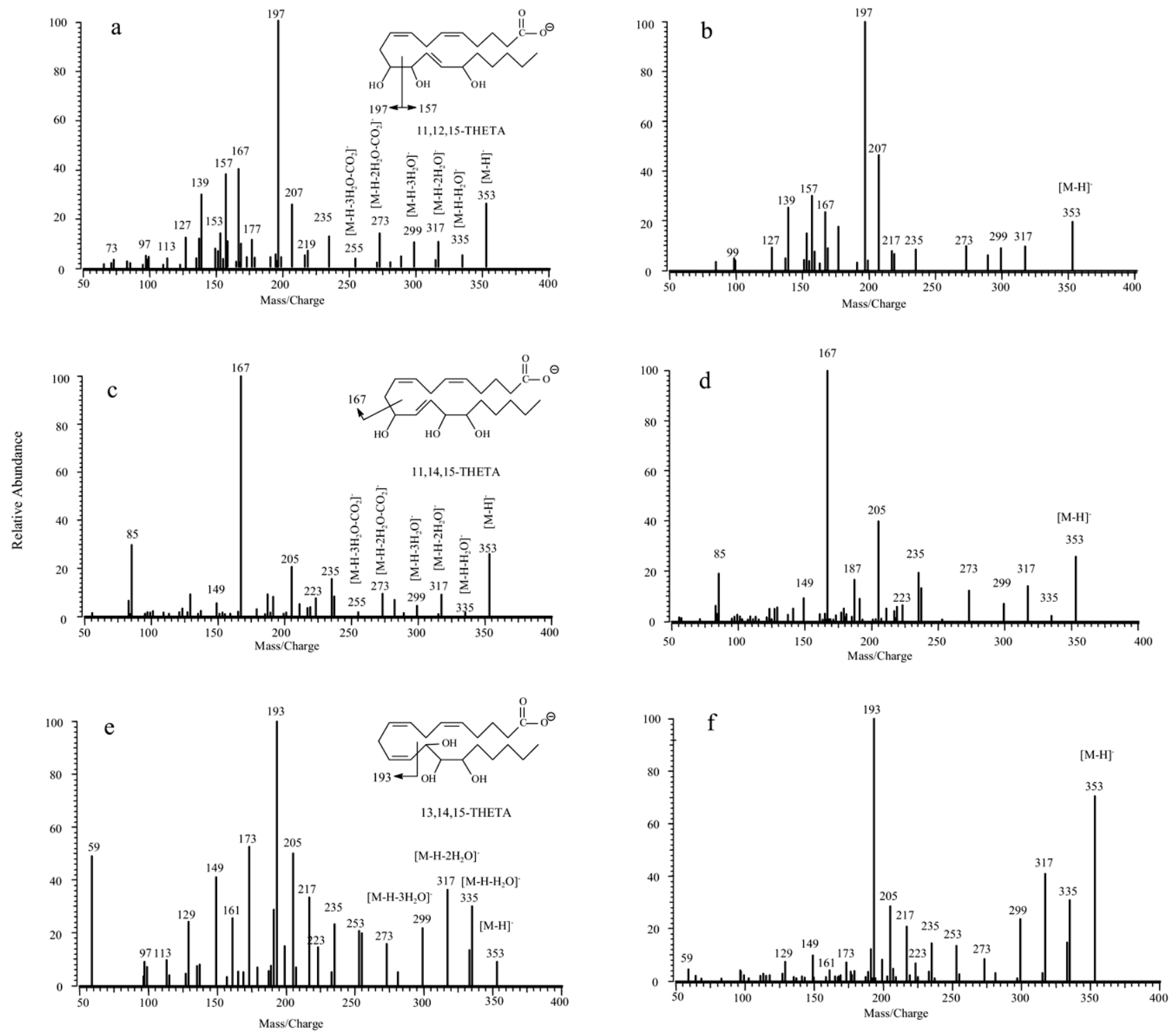

Figure 4. MS/MS spectra of $[\mathrm{M}-\mathrm{H}]^{-}, m / z 353$ for THETAs obtained from negative ion ESI SORI-CID and IRMPD FTICR. (a) MS/MS spectrum of 11,12,15-THETA by SORI-CID; (b) MS/MS spectrum of 11,12,15-THETA by IRMPD; (c) MS/MS spectrum of 11,14,15-THETA by SORI-CID; (d) MS/MS spectrum of 11,14,15-THETA by IRMPD; (e) MS/MS spectrum of 13,14,15-THETA by SORI-CID; (f) MS/MS spectrum of 13,14,15-THETA by IRMPD.

Table 3. High-resolution accurate mass measurements by SORI-CID FTICR for 11, 12, 15-THETA

\begin{tabular}{ccccc}
\hline Measured ions $(\mathrm{m} / \mathrm{z})$ & Calculated ions $(\mathrm{m} / \mathrm{z})$ & Error $(\mathrm{ppm})$ & Relative abundance $(\%)$ & Elemental composition \\
\hline \hline 353.23453 & 353.23335 & 3.3 & 25.57 & $\mathrm{C}_{20} \mathrm{H}_{33} \mathrm{O}_{5}{ }^{-1}$ \\
335.22580 & 335.22278 & 8.9 & 4.53 & $\mathrm{C}_{20} \mathrm{H}_{31} \mathrm{O}_{4}{ }^{1}$ \\
317.21342 & 317.21222 & 3.8 & 10.20 & $\mathrm{C}_{20} \mathrm{H}_{29} \mathrm{O}_{3}^{-1}$ \\
299.20257 & 299.20165 & 3.1 & 9.90 & $\mathrm{C}_{20} \mathrm{H}_{27} \mathrm{O}_{2}^{-1}$ \\
273.22319 & 273.22239 & 2.9 & 13.59 & $\mathrm{C}_{19} \mathrm{H}_{29} \mathrm{O}^{-1}$ \\
255.21169 & 255.21182 & -0.5 & 3.26 & $\mathrm{C}_{19} \mathrm{H}_{27}^{-1}$ \\
235.13449 & 235.13397 & 2.2 & 12.17 & $\mathrm{C}_{14} \mathrm{H}_{19} \mathrm{O}_{3}{ }^{-1}$ \\
207.13941 & 207.13905 & 1.7 & 25.31 & $\mathrm{C}_{13} \mathrm{H}_{19} \mathrm{O}_{2}^{-1}$ \\
197.11865 & 197.11832 & 1.7 & 100.00 & $\mathrm{C}_{11} \mathrm{H}_{17} \mathrm{O}_{3}^{-1}$ \\
167.10802 & 167.10775 & 1.6 & 39.96 & $\mathrm{C}_{10} \mathrm{H}_{15} \mathrm{O}_{2}^{-1}$ \\
157.12358 & 157.12340 & 1.1 & 38.32 & $\mathrm{C}_{9} \mathrm{H}_{17} \mathrm{O}_{2}{ }^{-1}$ \\
153.12883 & 153.12849 & 2.2 & 14.43 & $\mathrm{C}_{10} \mathrm{H}_{17} \mathrm{O}^{-1}$ \\
139.11300 & 139.11284 & 1.2 & 30.20 & $\mathrm{C}_{99} \mathrm{H}_{15} \mathrm{O}^{-1}$ \\
\hline
\end{tabular}


Table 4. High-resolution accurate mass measurements by SORI-CID FTICR for 11, 14, 15-THETA

\begin{tabular}{ccccc}
\hline Measured ions $(\mathrm{m} / \mathrm{z})$ & Calculated ions $(\mathrm{m} / \mathrm{z})$ & Error $(\mathrm{ppm})$ & Relative abundance $(\%)$ & Elemental composition \\
\hline \hline 353.23520 & 353.23335 & 5.2 & 26.34 & $\mathrm{C}_{20} \mathrm{H}_{33} \mathrm{O}_{5}{ }^{-1}$ \\
335.22255 & 335.22278 & -0.7 & 1.71 & $\mathrm{C}_{20} \mathrm{H}_{31} \mathrm{O}_{4}^{-1}$ \\
317.21416 & 317.21222 & 6.1 & 9.01 & $\mathrm{C}_{20} \mathrm{H}_{29} \mathrm{O}_{3}{ }^{-1}$ \\
299.20354 & 299.20165 & 6.3 & 4.44 & $\mathrm{C}_{20} \mathrm{H}_{27} \mathrm{O}_{2}^{-1}$ \\
273.22405 & 273.22239 & 6.1 & 9.48 & $\mathrm{C}_{19} \mathrm{H}_{29} \mathrm{O}^{-1}$ \\
255.21371 & 255.21182 & 7.4 & 1.89 & $\mathrm{C}_{19} \mathrm{H}_{27}^{-1}$ \\
235.13527 & 235.13397 & 5.5 & 15.85 & $\mathrm{C}_{14} \mathrm{H}_{29} \mathrm{O}_{3}{ }^{-1}$ \\
223.13530 & 223.13397 & 6.0 & 7.50 & $\mathrm{C}_{13} \mathrm{H}_{19} \mathrm{O}_{3}^{-1}$ \\
205.12465 & 205.12340 & 6.1 & 19.90 & $\mathrm{C}_{13} \mathrm{H}_{17} \mathrm{O}_{2}^{-1}$ \\
167.10833 & 167.10775 & 3.5 & 100.00 & $\mathrm{C}_{10} \mathrm{H}_{15} \mathrm{O}_{2}^{-1}$ \\
85.02952 & 85.02950 & 0.2 & 30.47 & $\mathrm{C}_{4}^{-1} \mathrm{H}_{5} \mathrm{O}_{2}^{-1}$ \\
\hline
\end{tabular}

HETEs and DHETs. In the SORI-CID and IRMPD spectra of $\mathrm{m} / \mathrm{z} 353$ of THETAs (Figure 4 and Tables 3, 4, and 5), which have three hydroxyl groups, the [M $\mathrm{H}]^{-}$ions easily lost one to three $\mathrm{H}_{2} \mathrm{O}$ molecules to give $\left[\mathrm{M}-\mathrm{H}-\mathrm{H}_{2} \mathrm{O}\right]^{-}(\mathrm{m} / \mathrm{z} 335),\left[\mathrm{M}-\mathrm{H}-2 \mathrm{H}_{2} \mathrm{O}\right]^{-}(\mathrm{m} / \mathrm{z}$ 317), and $\left[\mathrm{M}-\mathrm{H}-3 \mathrm{H}_{2} \mathrm{O}\right]^{-}(\mathrm{m} / \mathrm{z} 299)$. After the losses of 2 or $3 \mathrm{H}_{2} \mathrm{O},\left[\mathrm{M}-\mathrm{H}-2 \mathrm{H}_{2} \mathrm{O}\right]^{-}$and $\left[\mathrm{M}-\mathrm{H}-3 \mathrm{H}_{2} \mathrm{O}\right]^{-}$ could further dissociate to form $\left[\mathrm{M}-\mathrm{H}-2 \mathrm{H}_{2} \mathrm{O}-\right.$ $\left.\mathrm{CO}_{2}\right]^{-}(\mathrm{m} / \mathrm{z} 273)$ and $\left[\mathrm{M}-\mathrm{H}-3 \mathrm{H}_{2} \mathrm{O}-\mathrm{CO}_{2}\right]^{-}(\mathrm{m} / \mathrm{z}$ 255), respectively.

Compared with HETEs and DHETs, the relative intensities of these ions (loss of $\mathrm{H}_{2} \mathrm{O}$ and $\mathrm{CO}_{2}$ ) in THETAs were lower than in HETEs and DHETs. The results suggest that the carbon-carbon bond ruptures became the major fragments of THETAs. In the comparison of three THETAs, the relative intensities of ions corresponding to the losses of $\mathrm{H}_{2} \mathrm{O}$ and $\mathrm{CO}_{2}$ for 13,14,15-THETA were slightly higher than for $11,14,15$ and 11,12,15-THETA, suggesting that the positions of hydroxyl groups affected the losses of $\mathrm{H}_{2} \mathrm{O}$ and $\mathrm{CO}_{2}$ from the molecular ions. When three hydroxyl groups were adjacent, as with 13,14,15-THETA, it was easier to lose $\mathrm{H}_{2} \mathrm{O}$ or $\mathrm{CO}_{2}$.

\section{Unique Fragmentation Pathways for HETEs, DHETs, and THETAs}

Besides the similarities of fragmentation, there were significant differences in fragmentations among HETEs, DHETs, and THETAs obtained from SORI-CID and IRMPD that indicated the characteristics of the molecular structures.

(a) MS/MS Characteristics of HETEs by SORI-CID and IRMPD.

(1) SORI-CID of HETEs. Figure 2a, c, and e show the MS/MS spectra obtained from SORI-CID FTICR for 11-, $12-$, and 15-HETE, respectively. In the SORI-CID spectrum of $[\mathrm{M}-\mathrm{H}]^{-}$for 11-HETE, the major characteristic product ions were $m / z 167$ and 149 . The characteristic $\mathrm{m} / \mathrm{z} 167$ is similar to that reported fragmentation by triple quadrupole and ion trap mass spectrometers $[33,39,41]$. The MS/MS spectra for 11-HETE by a triple quadrupole mass spectrometer had the dominant ion of $m / z 167$ [33], while spectra from FTICR and ion trap [39] contained other characteristic ions. The mechanism for formation of $m / z 167$ was previously described [41] as the charge-remote formation of the aldehyde by proton

Table 5. High-resolution accurate mass measurements by SORI-CID FTICR for 13, 14, 15-THETA

\begin{tabular}{|c|c|c|c|c|}
\hline Measured ions $(\mathrm{m} / \mathrm{z})$ & Calculated ions $(\mathrm{m} / \mathrm{z})$ & Error (ppm) & Relative abundance (\%) & Elemental composition \\
\hline 353.23454 & 353.23335 & 3.4 & 9.16 & $\mathrm{C}_{20} \mathrm{H}_{33} \mathrm{O}_{5}^{-1}$ \\
\hline 335.22447 & 335.22278 & 5.0 & 29.95 & $\mathrm{C}_{20} \mathrm{H}_{31} \mathrm{O}_{4}^{-1}$ \\
\hline 317.21399 & 317.21222 & 5.6 & 36.52 & $\mathrm{C}_{20} \mathrm{H}_{29} \mathrm{O}_{3}^{-1}$ \\
\hline 299.20348 & 299.20165 & 6.1 & 21.78 & $\mathrm{C}_{20} \mathrm{H}_{27} \mathrm{O}_{2}^{-1}$ \\
\hline 273.22435 & 273.22239 & 7.2 & 15.69 & $\mathrm{C}_{19} \mathrm{H}_{29} \mathrm{O}^{-1}$ \\
\hline 255.21344 & 255.21182 & 6.3 & 20.02 & $\mathrm{C}_{19} \mathrm{H}_{27}{ }^{1}$ \\
\hline 253.14608 & 253.14453 & 6.1 & 20.85 & $\mathrm{C}_{14} \mathrm{H}_{21} \mathrm{O}_{4}^{-1}$ \\
\hline 235.13524 & 235.13397 & 5.4 & 23.23 & $\mathrm{C}_{14} \mathrm{H}_{19} \mathrm{O}_{3}^{-1}$ \\
\hline 223.13486 & 223.13397 & 4.0 & 14.73 & $\mathrm{C}_{13} \mathrm{H}_{19} \mathrm{O}_{3}^{-1}$ \\
\hline 217.12449 & 217.12340 & 5.0 & 33.61 & $\mathrm{C}_{14} \mathrm{H}_{17} \mathrm{O}_{2}^{-1}$ \\
\hline 205.12447 & 205.12340 & 5.2 & 50.50 & $\mathrm{C}_{13} \mathrm{H}_{17} \mathrm{O}_{2}^{-1}$ \\
\hline 193.12430 & 193.12340 & 4.7 & 100.00 & $\mathrm{C}_{12} \mathrm{H}_{17} \mathrm{O}_{2}^{-1}$ \\
\hline 173.13440 & 173.13357 & 4.8 & 52.43 & $\mathrm{C}_{13} \mathrm{H}_{17}{ }^{-1}$ \\
\hline 161.13442 & 161.13357 & 5.3 & 25.51 & $\mathrm{C}_{12} \mathrm{H}_{17}^{-1}$ \\
\hline 149.13423 & 149.13357 & 4.4 & 41.29 & $\mathrm{C}_{11} \mathrm{H}_{17}{ }^{-1}$ \\
\hline 129.09271 & 129.09210 & 4.7 & 24.04 & $\mathrm{C}_{7} \mathrm{H}_{13} \mathrm{O}_{2}^{-1}$ \\
\hline 59.01395 & 59.01385 & 1.7 & 49.36 & $\mathrm{C}_{2} \mathrm{H}_{3} \mathrm{O}_{2}{ }^{-1}$ \\
\hline
\end{tabular}


(a)
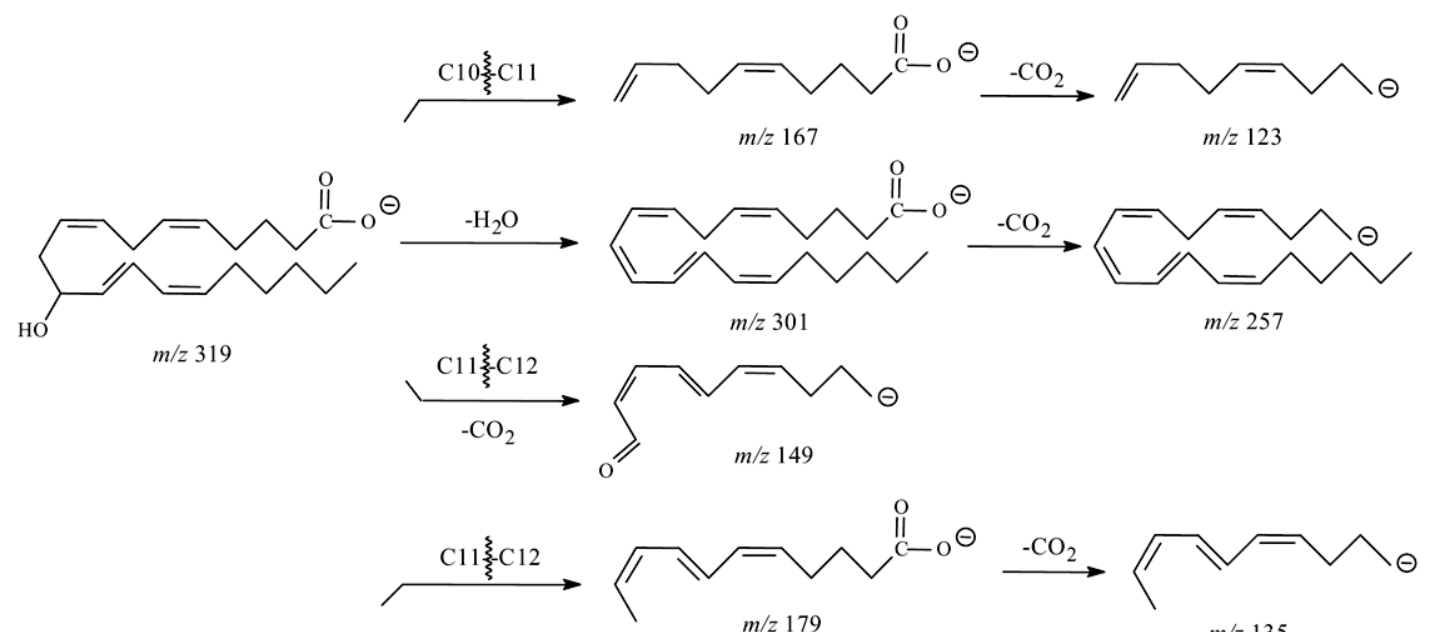

(b)

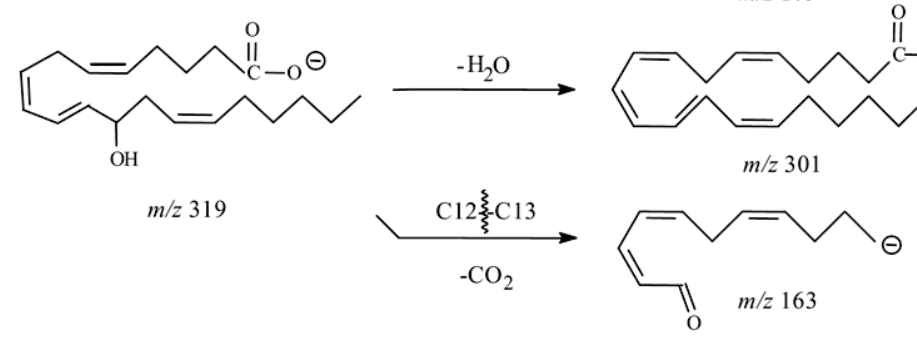

(c)

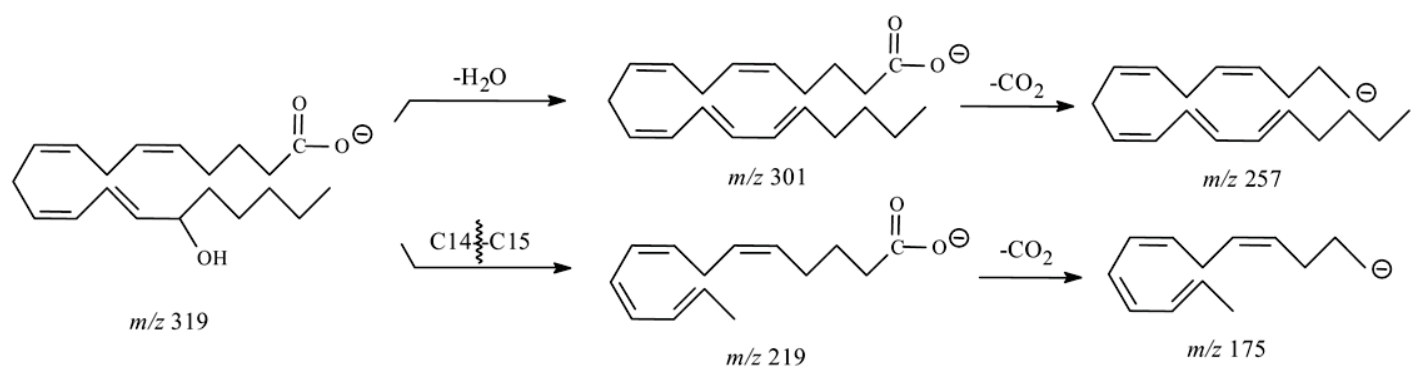

Scheme 1. Proposed major fragmentation pathways of 11-, 12- and 15-HETE by negative ion ESI-FTICR. (a) 11-HETE; (b) 12-HETE; (c) 15-HETE.

transfer and the cleavage of the C10-C11 bond. Another characteristic ion of the $\mathrm{m} / \mathrm{z} 149$ was observed and proposed as a cleavage of the $\mathrm{C} 11-\mathrm{C} 12$ bond and a loss of $\mathrm{CO}_{2}$. Another particular ion with high intensity was observed at $\mathrm{m} / \mathrm{z} 275$. It was formed by a direct loss of $\mathrm{CO}_{2}$ from the $[\mathrm{M}-\mathrm{H}]^{-}$ion. The losses of $\mathrm{CO}_{2}$ and $\mathrm{H}_{2} \mathrm{O}$ by $[\mathrm{M}-\mathrm{H}]^{-}$ion formed the highest abundant $\mathrm{m} / \mathrm{z} 257$, although these two ions were not detected in the previous studies [33, 41] (Scheme 1a).

For 12-HETE, the major characteristic ions were $\mathrm{m} / \mathrm{z}$ 179,163 , and 135 and were similar to the results from the ion trap mass spectrometer [39]. Again, the $\mathrm{m} / \mathrm{z} 257$ is the highest abundant ion. The mechanism for the $\mathrm{m} / \mathrm{z}$ 179 formation was previously described [41]. We proposed that the negative charge was located at the carboxylate because the presence of the $\mathrm{m} / \mathrm{z} 135$ ion, corresponding to a loss of $\mathrm{CO}_{2}$ from the $\mathrm{m} / \mathrm{z} 179$. The $\mathrm{m} / \mathrm{z}$ 163 was presumably the result of carbon-carbon bond cleavage from $\mathrm{C} 12-\mathrm{C} 13$ and loss of $\mathrm{CO}_{2}$ (Scheme 1b).

The characteristic product ions of 15-HETE were $\mathrm{m} / \mathrm{z}$ 219, 175, and 113 and were similar to previous studies
$[33,39]$. The $m / z 219$ was the product ion formed by the identical mechanism as previously described for the $\mathrm{m} / \mathrm{z}$ 179 of 12-HETE [41]. The $\mathrm{m} / \mathrm{z} 175$ was the subsequent loss of $\mathrm{CO}_{2}$ from the $\mathrm{m} / \mathrm{z} 219$ (Scheme 1c). The elemental composition of the $\mathrm{m} / \mathrm{z} 113$ indicated the fragment of $\mathrm{C}_{7} \mathrm{H}_{13} \mathrm{O}^{-1}$, suggesting the double-bond conjugation and cleavage of $\mathrm{C} 13-\mathrm{C} 14$ bond. The abundance of this ion increased in IRMPD (see below).

(2) IRMPD of HETEs. The major product ions generated from IRMPD were similar to those generated from SORI-CID, but the relative intensities of these ions were different. In IRMPD spectra of $[\mathrm{M}-\mathrm{H}]^{-}$for all three HETEs (Figure 2b, d, and f), the relative intensity of $\mathrm{m} / \mathrm{z} 257$ decreased, while this ion was the highest abundant ion in SORI-CID spectra of HETEs. It indicated that the loss of $\mathrm{CO}_{2}$ from the $\left[\mathrm{M}-\mathrm{H}-\mathrm{H}_{2} \mathrm{O}\right]^{-}$ion for HETEs became less effective with IRMPD. For 12-HETE (Figure 2d), m/z 179 was the most abundant ion, indicating that the break of $\mathrm{C} 11-\mathrm{C} 12$ bond was the major pathway [41]. For 15-HETE (Figure 2f), m/z 219 and 113 became the major ions. The $\mathrm{m} / \mathrm{z} 219$ was formed 


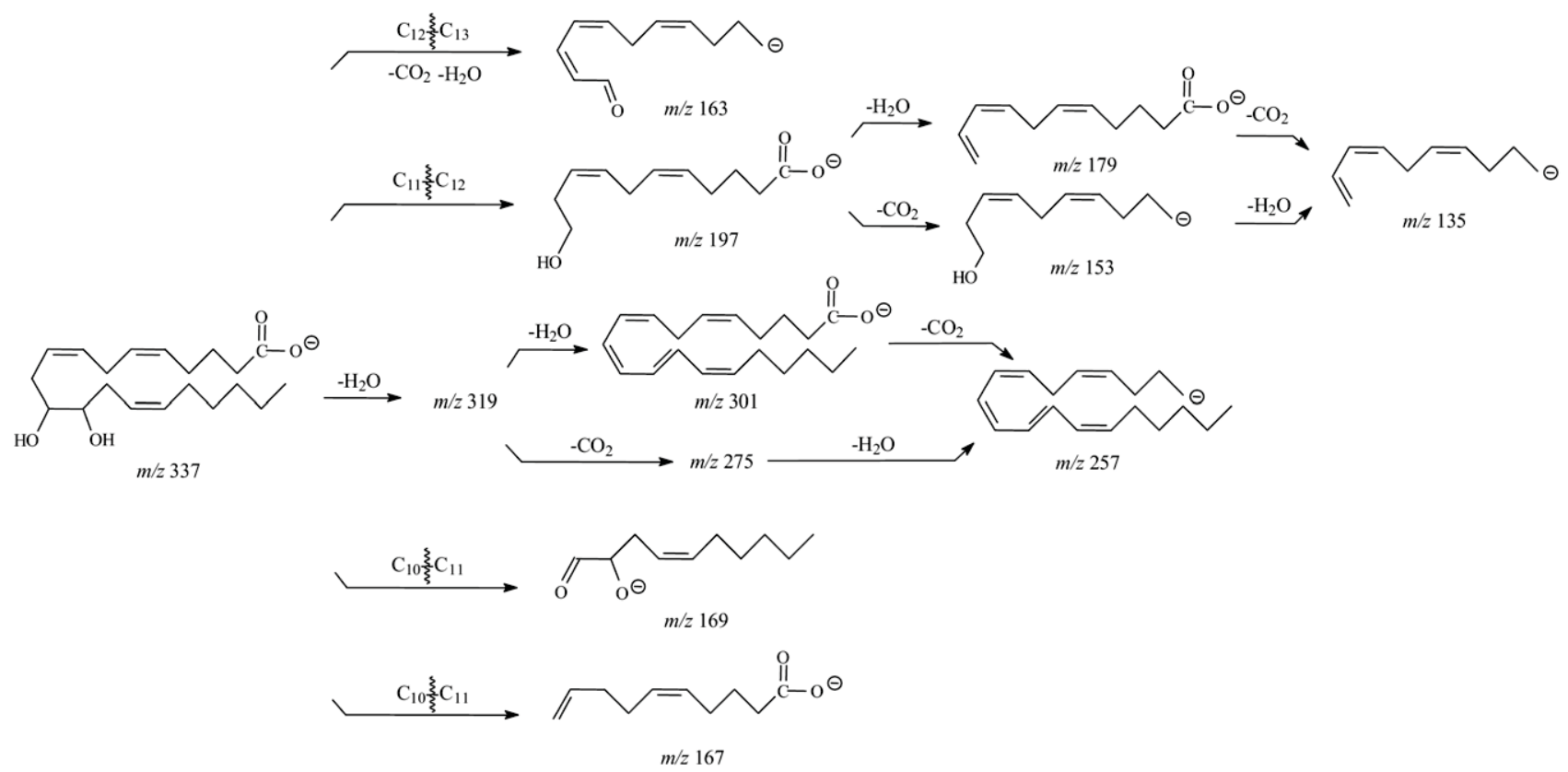

Scheme 2. Proposed major fragmentation pathways of 11,12-DHET by negative ion ESI FTICR.

by the break of C14-C15 bond and the charge was located on the carboxyl group. The formation of $m / z 113$ was the result of double-bond conjugation and the rupture of C13-C14 bond as in SORI-CID.

(b) MS/MS characteristics of DHETs by SORI-CID and IRMPD.

(1) SORI-CID of DHETs. In the SORI-CID spectrum of $[\mathrm{M}-\mathrm{H}]^{-}, m / z 337$, for 11,12 -DHET is shown in
Figure $3 \mathrm{a}$ and the ions are shown in Table 2. The prominent $m / z 167,163,135,179,197,153$, and 169 were observed and were similar to the results from ion trap mass spectrometer [39]. Formation of the highest abundant $m / z 167$ was similar to 11-HETE [41]. If the charge was relocated on the hydroxyl oxygen at $\mathrm{C} 12$, the $\mathrm{m} / \mathrm{z}$ 169 could be formed by the same fragmentation mechanism. The $m / z 197$ was a result of the cleavage of

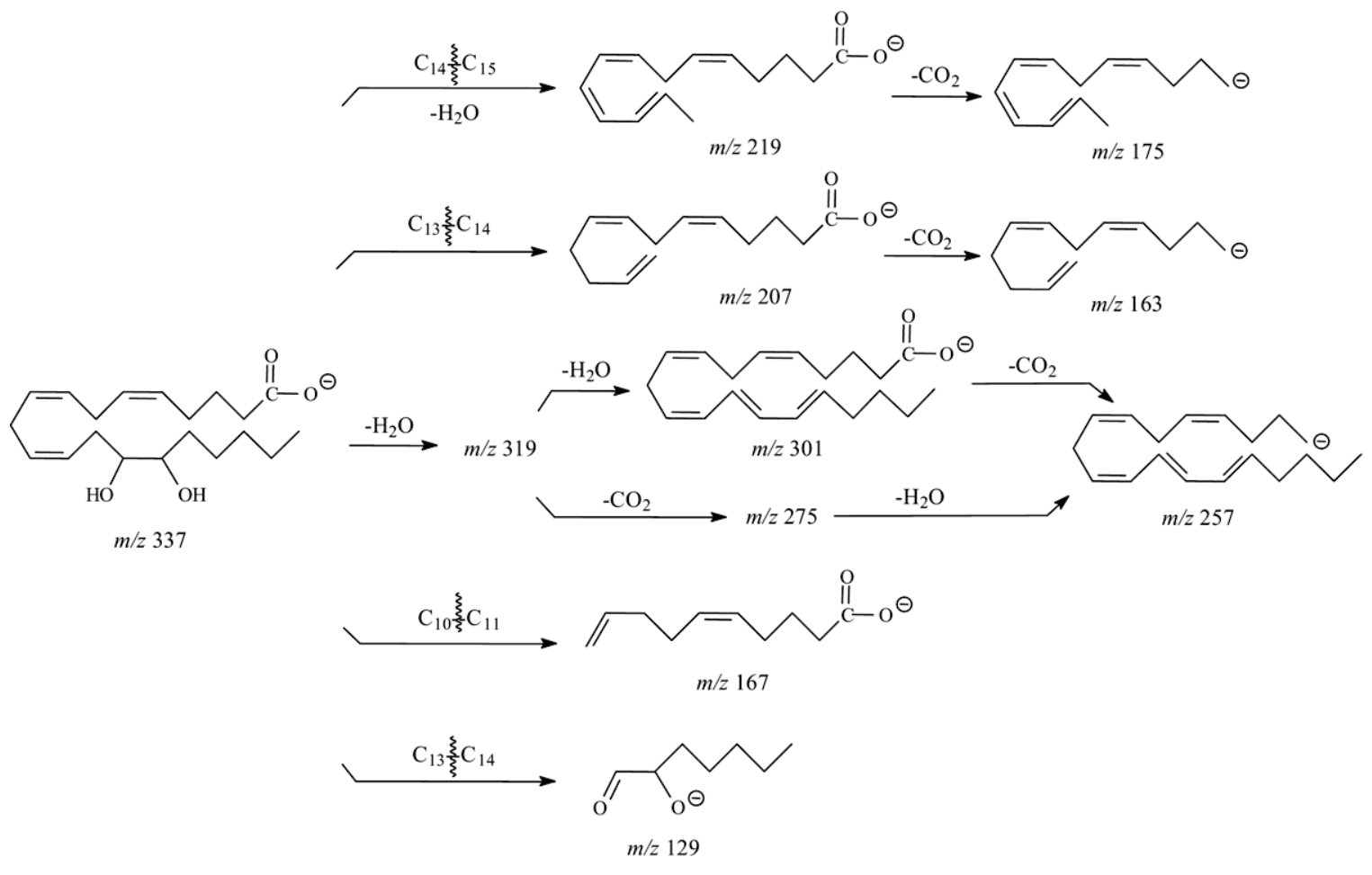

Scheme 3. Proposed major fragmentation pathways of 14,15-DHET by negative ion ESI FTICR. 


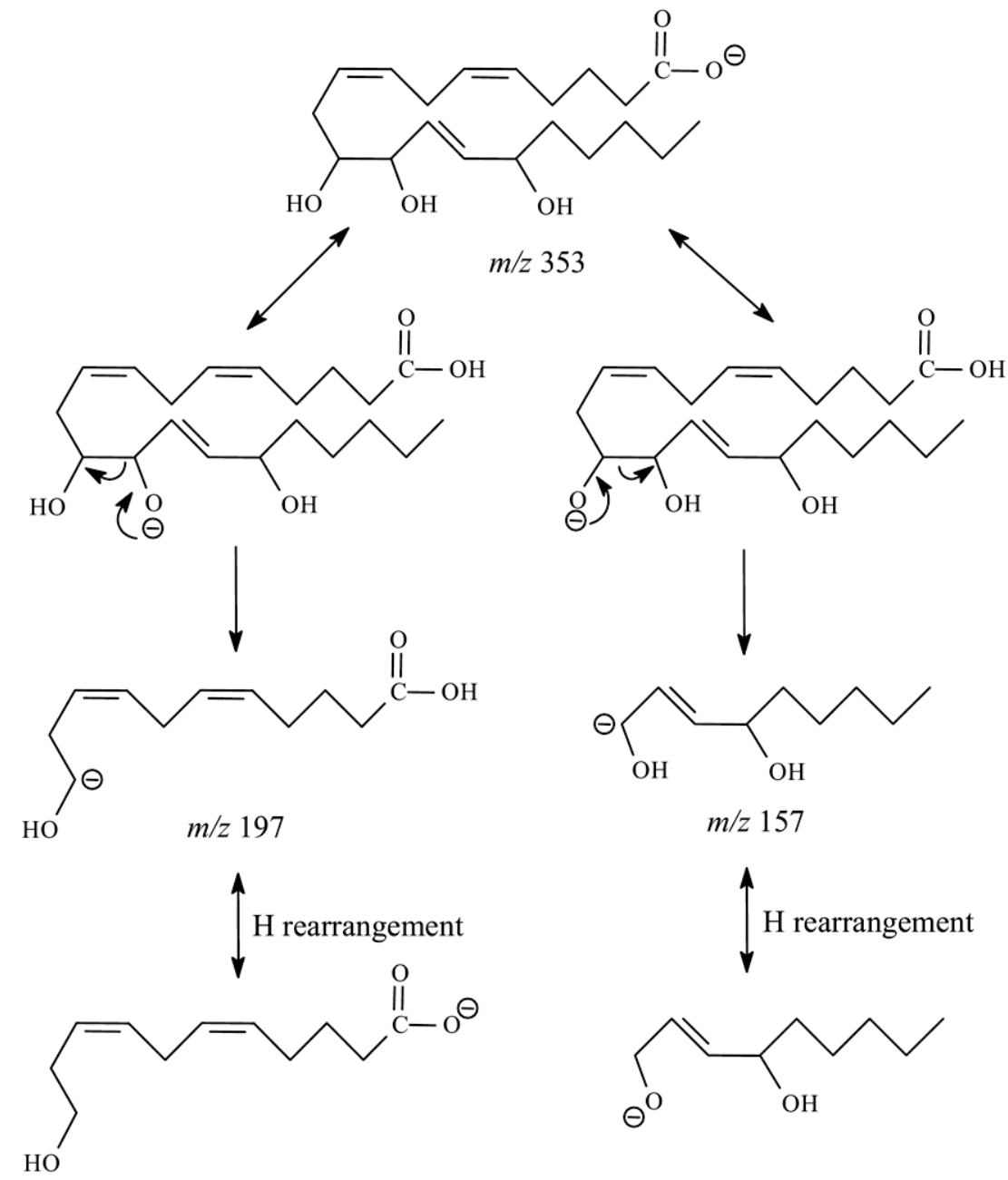

Scheme 4. Proposed mechanism of formation of the $\mathrm{m} / \mathrm{z} 197$ and $\mathrm{m} / \mathrm{z} 157$ in the negative ion SORI-CID spectrum of [M - H] $]^{-}$for 11,12,15-THETA.

C11-C12 bond [41]. Both $m / z 179$ and 153 corresponded to a loss of $\mathrm{H}_{2} \mathrm{O}$ and $\mathrm{CO}_{2}$ from the $\mathrm{m} / z 197$, respectively. The $\mathrm{m} / \mathrm{z} 135$ was formed by a loss of $\mathrm{CO}_{2}$ from the $\mathrm{m} / \mathrm{z}$ 179 or a loss of $\mathrm{H}_{2} \mathrm{O}$ from the $\mathrm{m} / z 153$, respectively. The $\mathrm{m} / \mathrm{z} 163$ was derived from the cleavage of $\mathrm{C} 12-\mathrm{C} 13$ and the losses of $\mathrm{H}_{2} \mathrm{O}$ and $\mathrm{CO}_{2}$. The major fragmentation pathways of 11,12-DHET were proposed in Scheme 2.

The CID spectrum of $[\mathrm{M}-\mathrm{H}]^{-}, m / z 337$, for $14,15-$ DHET had several characteristic ions (Table 2) that were similar to the results from the ion trap mass spectrometer [39] with the most abundant fragments of $\mathrm{m} / \mathrm{z} 207$ and 257 (Figure 3c). The $\mathrm{m} / \mathrm{z} 257$ was the result of the loss of $2 \mathrm{H}_{2} \mathrm{O}$ and $\mathrm{CO}_{2}$ from the $[\mathrm{M}-\mathrm{H}]^{-}$ion. The $\mathrm{m} / \mathrm{z}$ 207 was derived from the cleavage of the $\mathrm{C} 13-\mathrm{C} 14$ bond as previously described $[39,41]$. In addition to $m / z 207$, other major ions were observed at $m / z 129,163,175$, and 219. The $\mathrm{m} / \mathrm{z} 163$ was from a loss of $\mathrm{CO}_{2}$ from the $\mathrm{m} / \mathrm{z}$ 207. If the charge was relocated on the hydroxyl oxygen at $\mathrm{C} 15, \mathrm{~m} / \mathrm{z} 129$ can be formed at high abundance by the same dissociation as $\mathrm{m} / \mathrm{z} 207$. The $\mathrm{m} / \mathrm{z} 219$ resulted from a loss of $\mathrm{H}_{2} \mathrm{O}$ and the charge-driven cleavage of the $\mathrm{C} 14-\mathrm{C} 15$ bond from the molecular ion as described for
15-HETE above. The subsequent loss of $\mathrm{CO}_{2}$ by $\mathrm{m} / z 219$ formed $\mathrm{m} / \mathrm{z} 175$ with high abundance. Some other low abundant ions were also observed in the spectra, such as $\mathrm{m} / \mathrm{z} 127$ derived from cleavage at the C7-C8 bond, $\mathrm{m} / \mathrm{z} 167$ derived from the cleavage at the $\mathrm{C} 10-\mathrm{C} 11$ bond. Scheme 3 illustrates the proposed dissociation reactions of 14,15-DHET.

(2) IRMPD of DHETs. The IRMPD spectra of [M $\mathrm{H}]^{-}$for DHETs were similar to those formed by SORICID, indicating the same major fragmentation patterns. In the IRMPD spectra of $[\mathrm{M}-\mathrm{H}]^{-}$for $11,12-$ and 14,15-DHETs (Figure $3 \mathrm{~b}$ and d), the intensity of $\mathrm{m} / \mathrm{z} 257$ also decreased similar to HETEs as described above. The intensities of $\mathrm{m} / \mathrm{z} 319$ and 301, which were the results of the loss of one and two $\mathrm{H}_{2} \mathrm{O}$ from the molecular ions, became higher, indicating easy losses of $\mathrm{H}_{2} \mathrm{O}$ to produce $\left[\mathrm{M}-\mathrm{H}-\mathrm{H}_{2} \mathrm{O}\right]^{-}$and $[\mathrm{M}-\mathrm{H}-$ $\left.2 \mathrm{H}_{2} \mathrm{O}\right]^{-}$. Interestingly, the $\mathrm{m} / \mathrm{z} 163$ instead of $\mathrm{m} / \mathrm{z} 167$ was observed as the high abundant ion for 11,12-DHET (Figure 3b) similar to 12-HETE. The results suggested that 11,12 -DHET possibly lost $\mathrm{H}_{2} \mathrm{O}$ at the $\mathrm{C} 11$ position and fragmented with the mechanism similar to 12- 


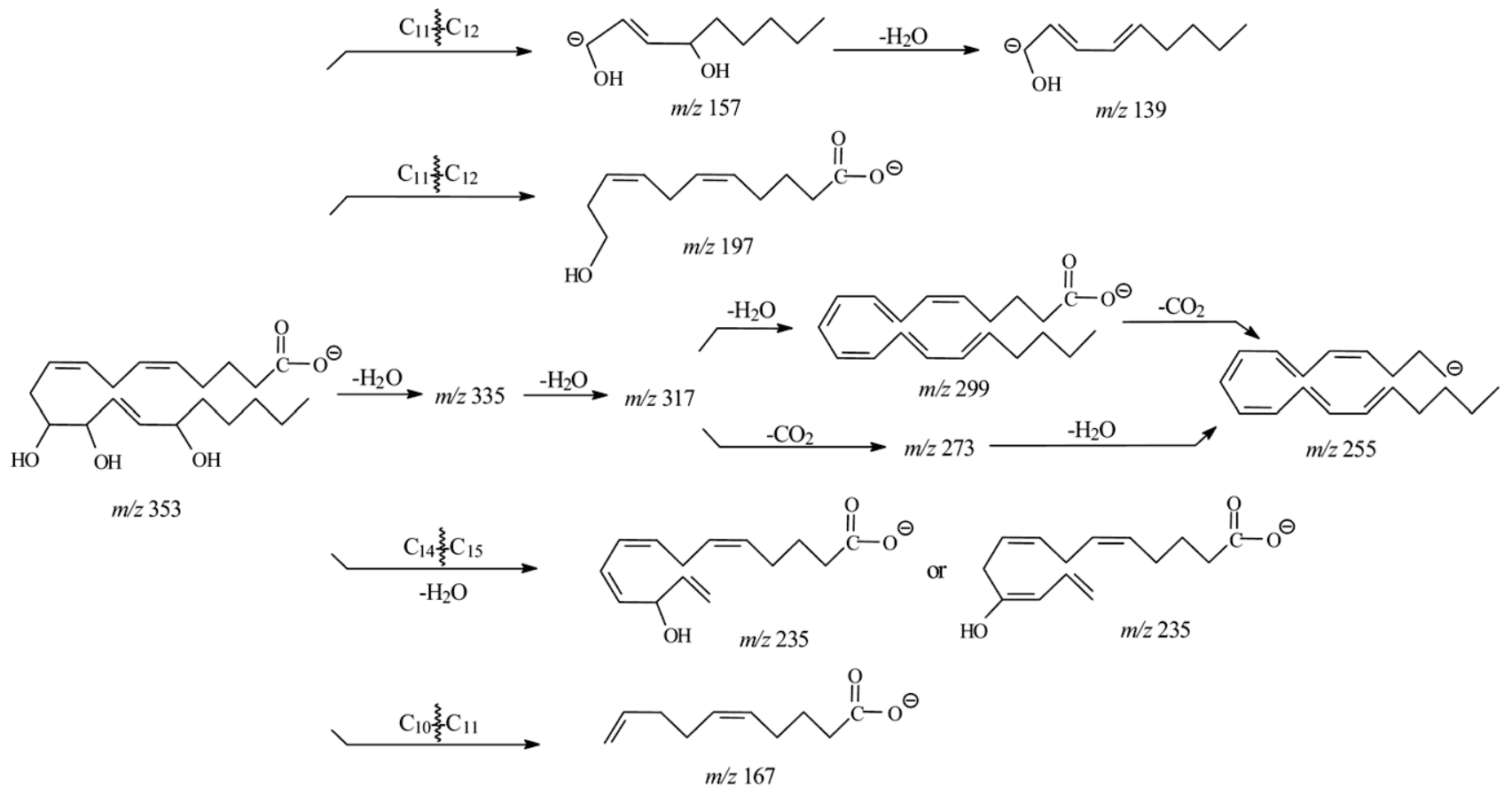

Scheme 5. Proposed fragmentation pathways of 11,12,15-THETA by negative ion ESI FTICR.

HETE. More low abundant ions were observed in the low $\mathrm{m} / \mathrm{z}$ range of the IRMPD spectrum of 11,12-DHET, such as $m / z 58,123,113,177$, and 139, indicating further fragmentation from excessive energy. For 14,15-DHET, the intensities of $\mathrm{m} / \mathrm{z} 175,163$, and 129 became lower in the IRMPD spectrum with the $\mathrm{m} / \mathrm{z} 207$ as the highest abundance ion (Figure 3d). This suggested the dominant $\mathrm{C}_{13}-\mathrm{C}_{14}$ cleavage.

In general, the major product ions in the CID spectra of HETEs and DHETs obtained from FTICR were similar to ions obtained from ion trap and triple quadrupole mass spectrometers [34-41]. However, more

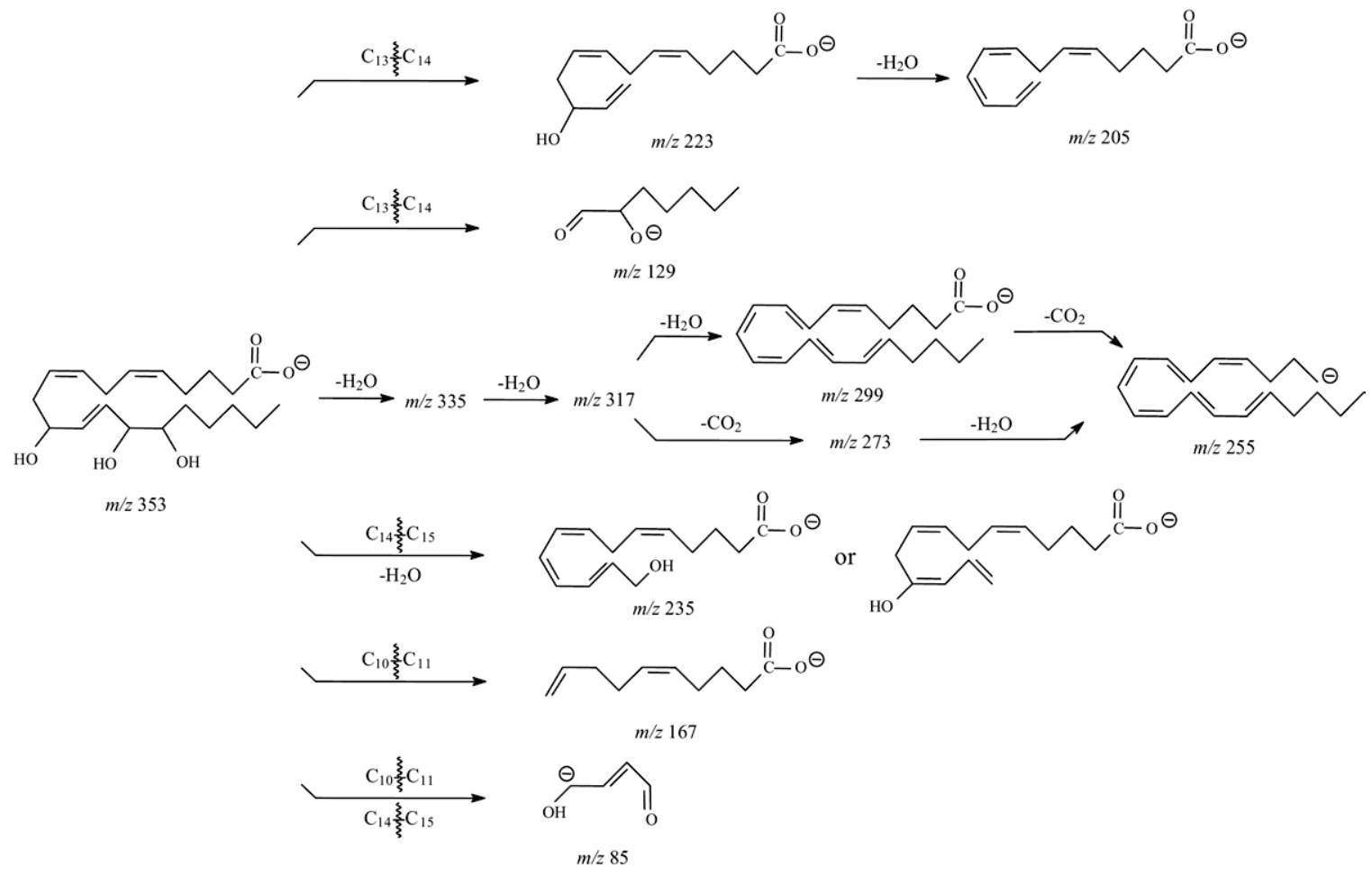

Scheme 6. Proposed fragmentation pathways of 11,14,15-THETA by negative ion ESI FTICR. 


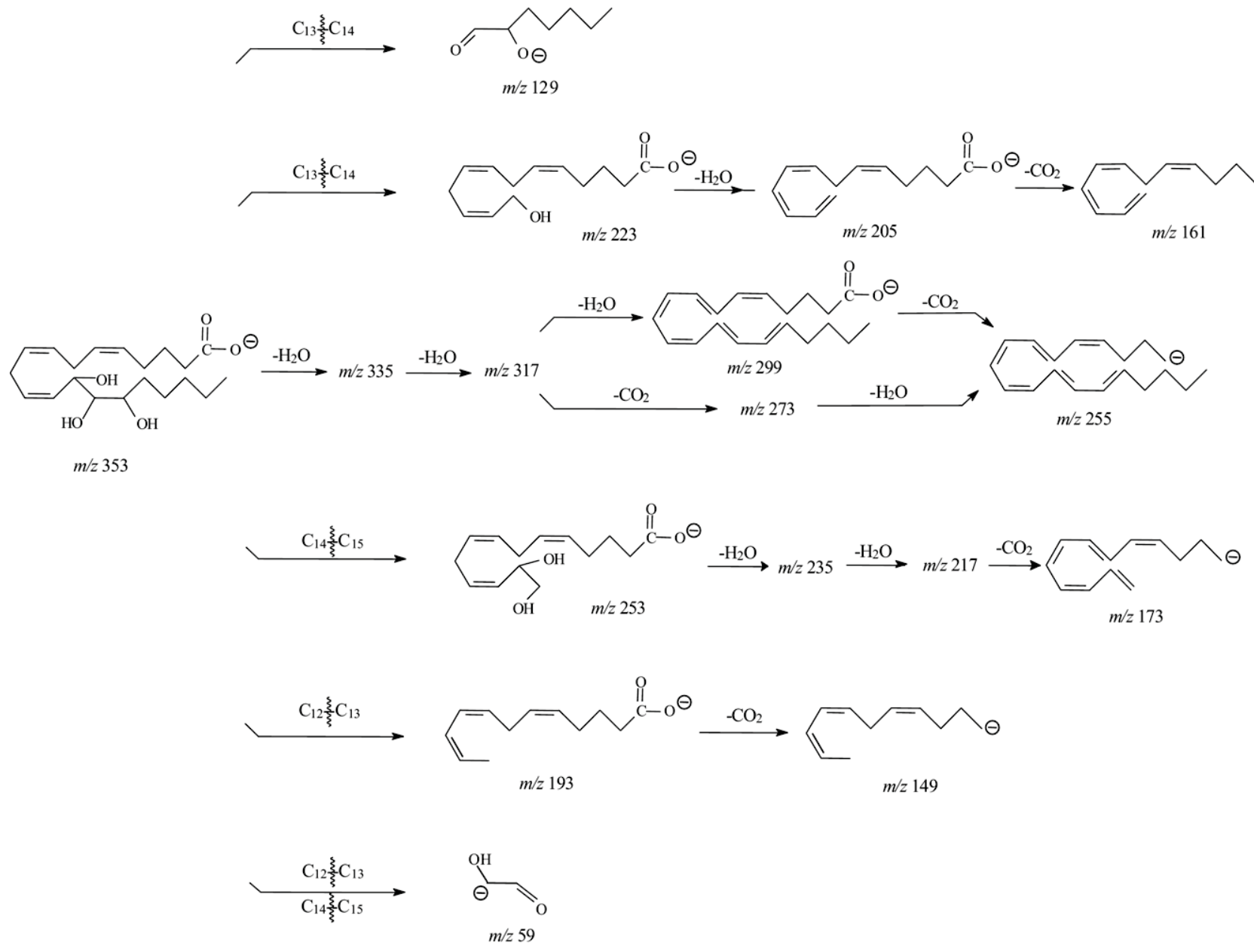

Scheme 7. Proposed fragmentation pathway of 13,14,15-THETA by negative ion ESI FTICR.

intense and more characteristic fragmentation ions were obtained from FTICR similar to ion trap than triple quadrupole mass spectrometry. Losses of $\mathrm{H}_{2} \mathrm{O}$ and $\mathrm{CO}_{2}$ to form characteristic ions are more favorable in FTICR. Furthermore, the structures of these fragments can be ascertained based on the corresponding high-resolution and accurate mass data from FTICR. For example, the $\mathrm{m} / \mathrm{z} 163$ for 12-HETE and 11,12-DHET has the masses of $163.11,239$ and $163.11,235$, respectively. This ion has the elemental composition of $\mathrm{C}_{11} \mathrm{H}_{15} \mathrm{O}^{-1}$ (Tables 1 and 2). However, the $\mathrm{m} / z 163$ for 14,15-DHET has the mass of 163.14,947 with the elemental composition of $\mathrm{C}_{12} \mathrm{H}_{19}{ }^{-1}$ (Table 2). These results indicated that the fragmentation mechanisms of the $\mathrm{m} / \mathrm{z}$ 163 for 12-HETE/11,12-DHET, and 14,15-DHET are different as shown in Schemes 1, 2, and 3.

(c) MS/MS Characteristics of THETAs by SORI-CID and IRMPD.

(1) SORI-CID of THETAs. All THETAs exhibited identical $[\mathrm{M}-\mathrm{H}]^{-}, m / z 353$. Figure $4 \mathrm{a}, \mathrm{c}$, and e show the MS/MS spectra obtained from SORI-CID FTICR of $11,12,15-, 11,14,15-$, and 13,14,15-THETA, respectively. Their high-resolution and accurate mass spectrometric data and corresponding predicted elemental composi- tion of their fragments are shown in Tables 3, 4, and 5, respectively. With three hydroxyl groups, the spectra of THETAs were more complex than spectra of HETEs and DHETs.

For 11,12,15-THETA, (Figure 4a and Table 3), the major ions were $m / z 197,167,157,139$, and 127 . The most abundant product ion was $\mathrm{m} / \mathrm{z} 197$. This ion was the result of the charge-driven cleavage of C11-C12 by the loss of neutral aldehyde from the enolate anion in which the charge was relocated on the hydroxyl oxygen at C12. If the charge was relocated on the hydroxyl oxygen at C11, the $\mathrm{m} / \mathrm{z} 157$ was formed by the similar fragmentation mechanism as shown in Scheme 4. The $m / z 157$ then lost $\mathrm{H}_{2} \mathrm{O}$ to form $\mathrm{m} / \mathrm{z} 139$. The mechanism for formation of $\mathrm{m} / \mathrm{z} 167$ was the same as the ion of 11-HETE [41]. If the charge was relocated on the hydroxyl oxygen at $\mathrm{C} 15$, the $\mathrm{m} / \mathrm{z} 235$ was likely formed by the losses of $\mathrm{H}_{2} \mathrm{O}$ and hexyl aldehyde from the cleavage of $\mathrm{C} 14-\mathrm{C} 15$ bond. Scheme 5 illustrates the proposed fragmentation pathways for 11,12,15-THETA.

The SORI-CID spectrum of [M - H] $]^{-}$for $11,14,15-$ THETA (Figure $4 \mathrm{c}$ and Table 4 ) was dominated by the $\mathrm{m} / \mathrm{z}$ 167. The formation of the $\mathrm{m} / \mathrm{z} 167$ was the result of the double-bond conjugation and then, the break of 


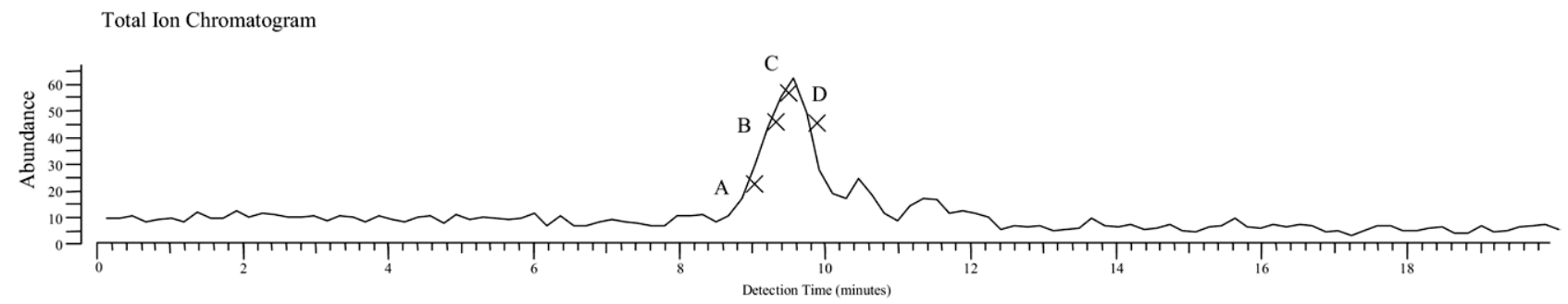

a Detection Time $=8.95 \mathrm{~min}$

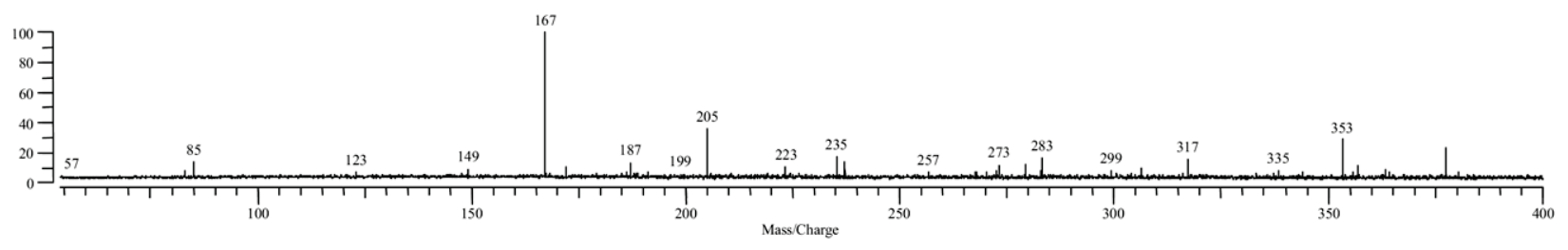

b Detection Time $=9.28 \mathrm{~min}$

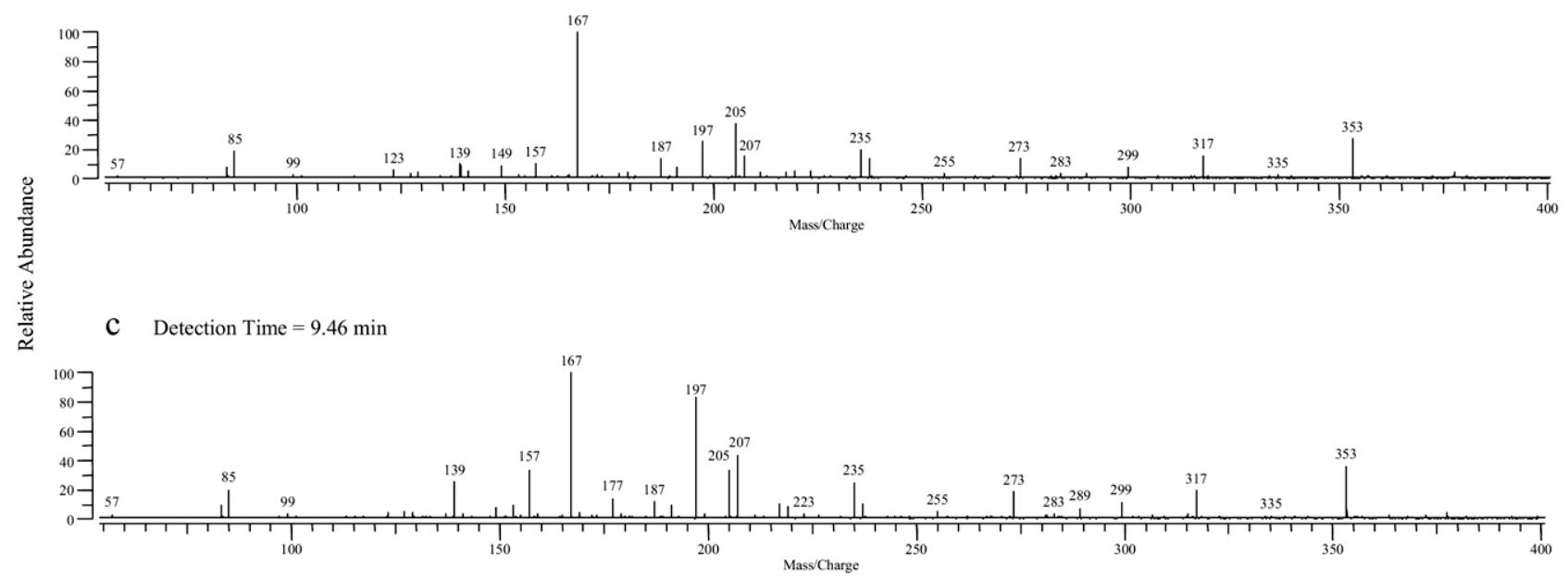

d Detection Time $=9.64 \mathrm{~min}$

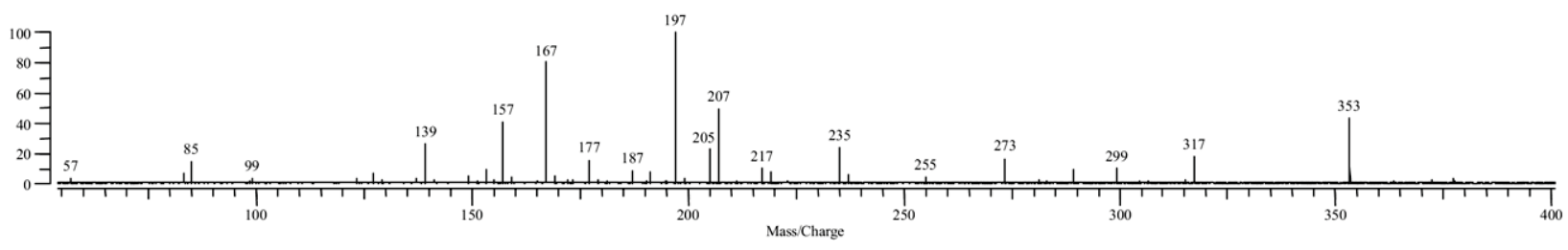

Figure 5. Total ion chromatogram (top panel) and product ion mass spectra of THETAs isolated from rabbit aorta by negative ion LC-ESI-FTICR with IRMPD. MS/MS spectrum of $\mathrm{m} / \mathrm{z} 353$ obtained from negative ion ESI FTICR at detection time of (a) $8.93 \mathrm{~min}$; (b) $9.28 \mathrm{~min}$; (c) $9.46 \mathrm{~min}$; (d) $9.64 \mathrm{~min}$.

C10-C11 bond as previously described for 11-HETE [41]. In addition, the unique characteristic $\mathrm{m} / \mathrm{z} 85$ was observed for 11,14,15-THETA. The elemental composition of this ion was assigned as $\mathrm{C}_{4} \mathrm{H}_{5} \mathrm{O}_{2}{ }^{-1}$. The proposed mechanism for its formation was the cleavages of $\mathrm{C} 10-\mathrm{C} 11$ bond and $\mathrm{C} 14-\mathrm{C} 15$ bond. Besides the $\mathrm{m} / \mathrm{z} 167$ and 85 , the $m / z 129,205,223$, and 235 were also observed for 11,14,15-THETA. The proposed fragmen- tation pathways for these ions were similar to DHETs as shown in Scheme 6.

When 11,12,15- and 11,14,15-THETA were compared, 11,12,15-THETA needed more collisional energy to fragment than 11,14,15-THETA. The different positions of the second hydroxyl group and the third double-bond in the structures of 11,12,15-THETA and 11,14,15-THETA resulted in a remarkable and diagnos- 
Table 6. High-resolution accurate mass measurements by IRMPD FTICR for biological samples

\begin{tabular}{cccc}
\hline $\begin{array}{c}\text { Measured ions } \\
(\mathrm{m} / \mathrm{z})\end{array}$ & $\begin{array}{c}\text { Calculated ions } \\
(\mathrm{m} / \mathrm{z})\end{array}$ & $\begin{array}{c}\text { Error } \\
(\mathrm{ppm})\end{array}$ & $\begin{array}{c}\text { Elemental } \\
\text { composition }\end{array}$ \\
\hline \hline 353.23141 & 353.23335 & -5.5 & $\mathrm{C}_{20} \mathrm{H}_{33} \mathrm{O}_{5}{ }^{-1}$ \\
317.21112 & 317.21222 & -3.5 & $\mathrm{C}_{20} \mathrm{H}_{29} \mathrm{O}_{3}{ }^{-1}$ \\
299.20090 & 299.20165 & -2.5 & $\mathrm{C}_{20} \mathrm{H}_{27} \mathrm{O}_{2}{ }^{-1}$ \\
273.22148 & 273.22239 & -3.5 & $\mathrm{C}_{19} \mathrm{H}_{29} \mathrm{O}^{-1}$ \\
235.13307 & 235.13397 & -3.8 & $\mathrm{C}_{14} \mathrm{H}_{19} \mathrm{O}_{3}{ }^{-1}$ \\
207.13821 & 207.13905 & -4.1 & $\mathrm{C}_{13} \mathrm{H}_{19} \mathrm{O}_{2}{ }^{-1}$ \\
205.12257 & 205.12340 & -4.0 & $\mathrm{C}_{13} \mathrm{H}_{17} \mathrm{O}_{2}{ }^{-1}$ \\
197.11747 & 197.11832 & -4.3 & $\mathrm{C}_{11} \mathrm{H}_{17} \mathrm{O}_{3}{ }^{-1}$ \\
167.10673 & 167.10775 & -6.1 & $\mathrm{C}_{10} \mathrm{H}_{15} \mathrm{O}_{2}^{-1}$ \\
157.12265 & 157.12340 & -4.8 & $\mathrm{C}_{9} \mathrm{H}_{17} \mathrm{O}_{2}{ }^{-1}$ \\
139.11211 & 139.11284 & -5.2 & $\mathrm{C}_{9} \mathrm{H}_{15} \mathrm{O}^{-1}$ \\
85.02898 & 85.02950 & -6.1 & $\mathrm{C}_{4} \mathrm{H}_{5} \mathrm{O}_{2}{ }^{-1}$ \\
\hline
\end{tabular}

tically useful difference in their major fragmentation pathways. The $\mathrm{m} / \mathrm{z}$ 197, 207, 157, and 139 were the characteristic product ions with $\mathrm{m} / \mathrm{z} 197$ as the highest abundant ion for 11,12,15-THETA. The $m / z 167,205$, and 85 were the characteristic product ions with $\mathrm{m} / \mathrm{z} 167$ as the most abundant ion for 11,14,15-THETA.

Figure $4 \mathrm{e}$ and Table 5 show the SORI CID spectrum and fragments of $[\mathrm{M}-\mathrm{H}]^{-}$for $13,14,15-\mathrm{THETA}$. The $\mathrm{m} / \mathrm{z} 193$ was observed as the most abundant ion, which was proposed to form by the double-bond conjugation and the break of $\mathrm{C} 12-\mathrm{C} 13$ bond similar to the formation of $\mathrm{m} / \mathrm{z} 179$ for 12-HETE [41]. This ion then lost $\mathrm{CO}_{2}$ to form the $\mathrm{m} / \mathrm{z} 149$. Other product ions were $\mathrm{m} / \mathrm{z} 253,235$, $223,217,205,173,161$, and 129 . If the charge was relocated at C15 oxygen group, the $\mathrm{m} / \mathrm{z} 253$ was formed by the charge-driven loss of neutral aldehyde from $\mathrm{C} 14-\mathrm{C} 15$ bond. The $\mathrm{m} / \mathrm{z} 235,217$, and 173 were formed by the losses of $\mathrm{H}_{2} \mathrm{O}$ or $\mathrm{CO}_{2}$ from $\mathrm{m} / \mathrm{z} 253$. The $\mathrm{m} / \mathrm{z} 223$ and 129 were formed by breaking of the $\mathrm{C} 13-\mathrm{C} 14$ bond. The former ion lost $\mathrm{H}_{2} \mathrm{O}$ to form the $\mathrm{m} / \mathrm{z} 205$, and then lost $\mathrm{CO}_{2}$ to produce the $\mathrm{m} / \mathrm{z} 161$. The unique characteristic $\mathrm{m} / \mathrm{z} 59$ was observed for $13,14,15$-THETA. The proposed formation of this ion was the cleavage of C12-C13 bond and C14-C15 bond similar to the $\mathrm{m} / \mathrm{z} 85$ for 11,14,15-THETA. The proposed fragmentation pathways for 13,14,15-THETA are shown in Scheme 7.

(2) IRMPD of THETAs. Figure $4 b, d$, and $f$ show the product ion spectra obtained from IRMPD of 11,12,15-, 11,14,15-, and 13,14,15-THETA, respectively. The major product ions obtained from IRMPD were similar to SORI-CID, suggesting similar major fragmentation pathways of THETAs. However, there were some differences between SORI-CID and IRMPD spectra. For 11,14,15-THETA (Figure 4d), the intensities of the $\mathrm{m} / \mathrm{z}$ 205 in the IRMPD spectrum increased 2-fold, and the abundance of $\mathrm{m} / \mathrm{z} 85$ decreased, compared with SORICID. IRMPD favored the $\mathrm{m} / \mathrm{z} 205$ by the cleavage of neutral aldehyde from $\mathrm{C} 13-\mathrm{C} 14$ bond and the subsequent loss of $\mathrm{H}_{2} \mathrm{O}$. This may be due to the product ion obtaining more energy from the laser, and then fragmentation to generate higher abundant $\mathrm{m} / \mathrm{z} 205$. For $11,12,15$-THETA, the relative abundance of the $\mathrm{m} / \mathrm{z} 207$ increased with IRMPD. However, the abundance of the other product ions, such as $m / z 157,167,177,139$, and 127, decreased. For 13,14,15-THETA, there were obvious differences between IRMPD and SORI-CID. The abundance of the $\mathrm{m} / \mathrm{z} 59$ and 173 decreased ten-fold in the IRMPD spectrum, and the other ions such as $\mathrm{m} / \mathrm{z}$ 205, 149, 129, 217, 235, and 253 also decreased. These two techniques complemented each other, providing more useful structural information.

\section{Identification of THETAs as Arachidonic Acid Metabolites in Rabbit Aorta Samples}

The THETA fraction in rabbit aorta samples was analyzed by negative ion LC-FTICR to obtain structural information for identification of THETA isomers. The mass spectrum of the samples showed the most abundant ion of $m / z 353\left([\mathrm{M}-\mathrm{H}]^{-}\right)$. The molecular weight was determined as $354 \mathrm{Da}$ with the elemental composition of $\mathrm{C}_{20} \mathrm{H}_{34} \mathrm{O}_{5}$.

Figure 5 (top panel) shows the total ion chromatogram of the MS/MS of $\mathrm{m} / \mathrm{z} 353$ by IRMPD. Figure $5 \mathrm{a}, \mathrm{b}, \mathrm{c}$, and d show the product ions of $m / z 353$ obtained from different retention times by IRMPD. The $m / z$ 335, 317, and 299 were observed, suggesting the subsequent losses of one to three $\mathrm{H}_{2} \mathrm{O}$ from $[\mathrm{M}-\mathrm{H}]^{-}$. These ions indicated three $\mathrm{OH}$ groups were present in the structures. The low abundance of these ions also suggested that the positions of three $\mathrm{OH}$ groups were not adjacent. The changes in spectral patterns at different retention times (from a to d) suggested that the peak contained more than one compound. A complete separation of THETA regioisomers on a reverse phase LC column was not obtained.

These mass spectra revealed the presence of characteristic products, $m / z 85,167,205,197,157,139$, and 207, which belonged to THETAs (Table 6). The $\mathrm{m} / \mathrm{z}$ 167,205 , and 85 were the characteristics of $11,14,15-$ THETA, and the $m / z 197,157,139$, and 207 were the characteristics of 11,12,15-THETA. As shown in Figure $5 \mathrm{a}$, the characteristics of $11,14,15$-THETA, such as $\mathrm{m} / \mathrm{z} 167,205$, and 85 , were observed, but no $\mathrm{m} / \mathrm{z} 197$, 157,139 , and 207 were observed, suggesting that $11,14,15$-THETA eluted first. With a longer eluting time (as shown in Figure 5b, c, and d), the $\mathrm{m} / \mathrm{z} 197$, 157,139 , and 207 appeared and the intensities of these ions increased, suggesting that 11,12,15-THETA eluted after 11,14,15-THETA.

Figure 6 shows the total ion chromatograms (top panel by IRMPD) and the selected ion chromatograms of $m / z$ 85, 139, 157, 167, 197, 205, and 207 by both SORI-CID and IRMPD. The $m / z$ 167, the major ion for 11,14,15-THETA and the minor ion for 11,12,15-THETA, exhibited a broad peak. According to the different retention times of these ions (run time of $25.00 \mathrm{~min}+$ detection time), the ions could be divided into two groups; a group of $m / z$ 167, 205, and 85 (Figure 6c, e, g, and $\mathrm{d}, \mathrm{f}, \mathrm{h}$ ) with identical detection times (9.44 $\mathrm{min}$ ), suggesting that they were generated from one compound, 11,14,15-THETA, and another group of $\mathrm{m} / \mathrm{z}$ 
a Total Ion Chromatogram

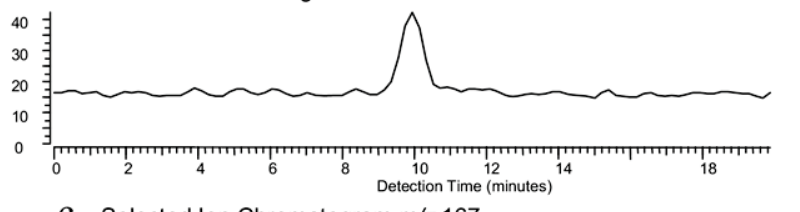

C Selected Ion Chromatogram $\mathrm{m} / \mathrm{z} 167$

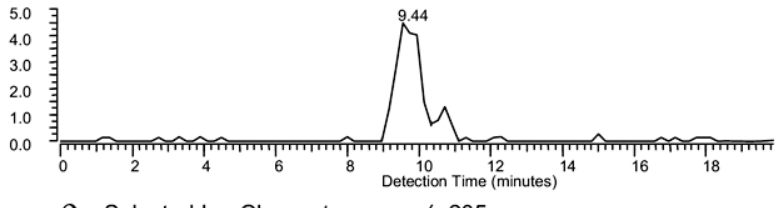

e Selected Ion Chromatogram m/z 205

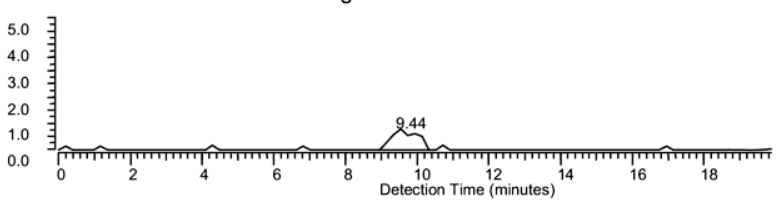

g Selected lon Chromatogram $\mathrm{m} / \mathrm{z} 85$

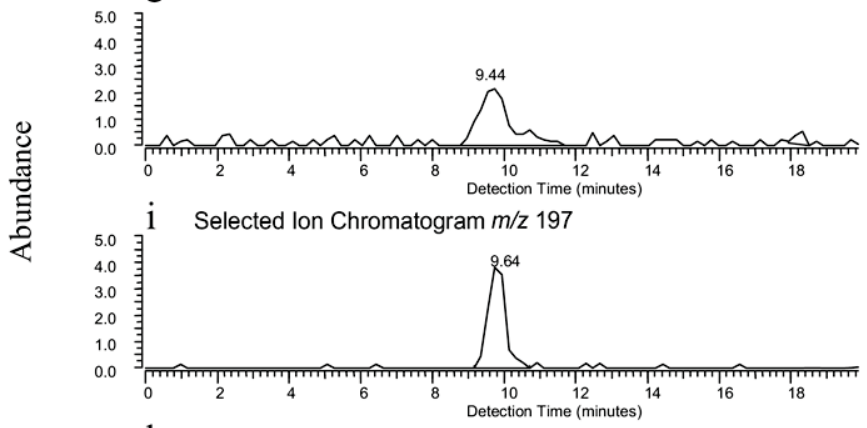

$\mathrm{k}$ Selected lon Chromatogram $\mathrm{m} / \mathrm{z} 157$

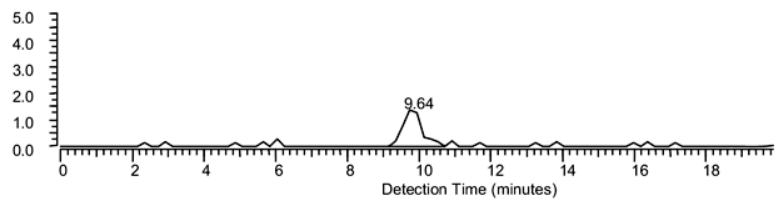

$\mathrm{m}$ Selected Ion Chromatogram m/z 139

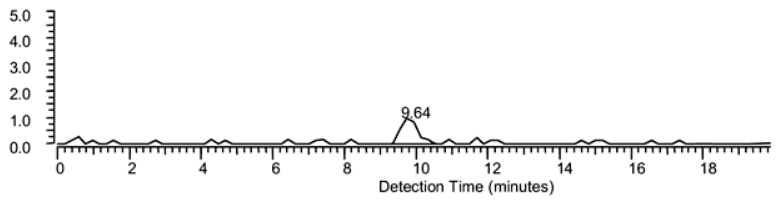

O Selected Ion Chromatogram m/z 207

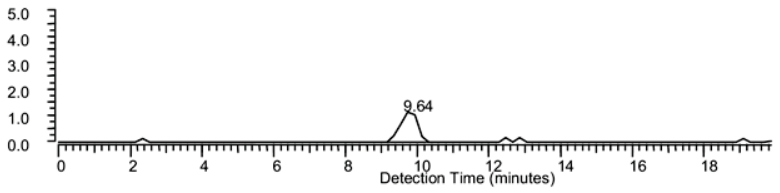

b Total Ion Chromatogram

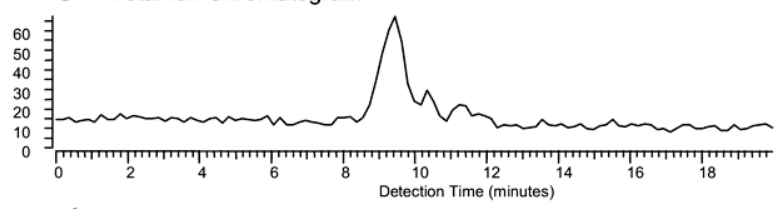

d Selected Ion Chromatogram m/z 167

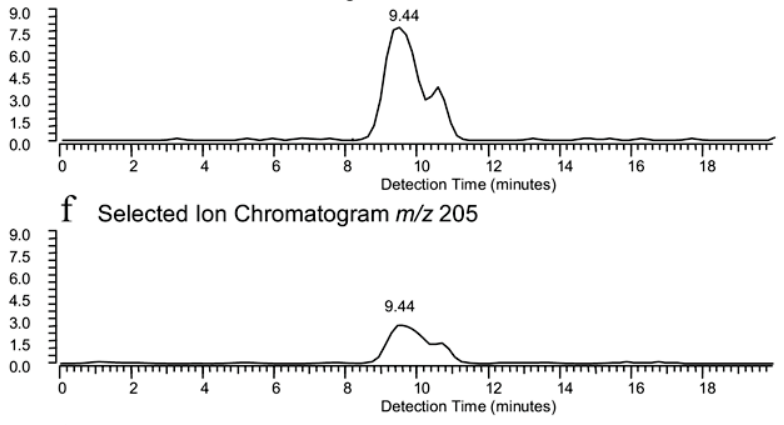

h Selected Ion Chromatogram $\mathrm{m} / \mathrm{z} 85$

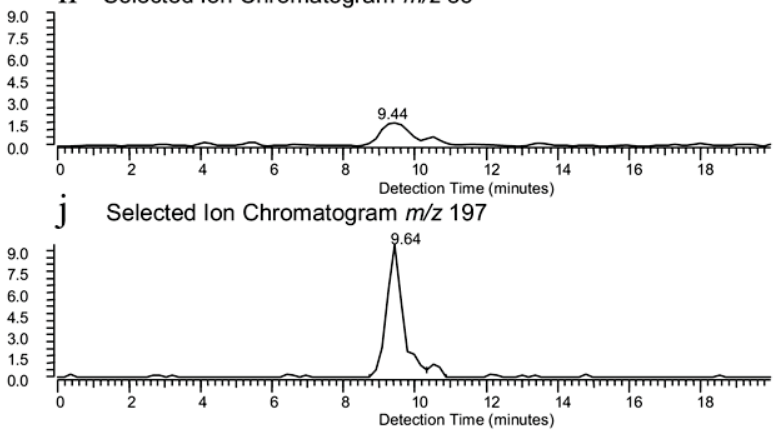

1 Selected Ion Chromatogram m/z 157

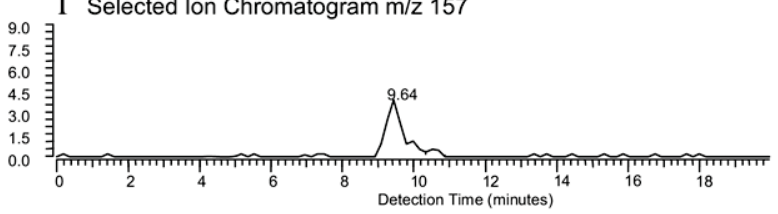

n Selected lon Chromatogram $\mathrm{m} / \mathrm{z} 139$

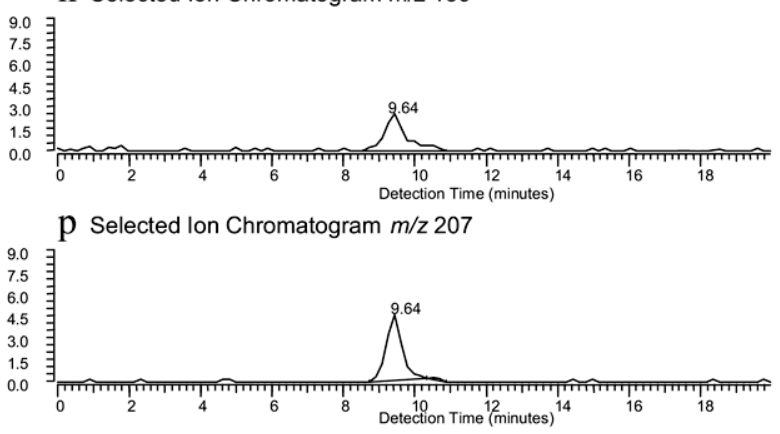

Figure 6. Total ion chromatograms and selected ion chromatograms of THETA fraction (top panels) isolated from rabbit aorta by negative ion LC-ESI-FTICR with SORI-CID and IRMPD. Total ion chromatograms by SORI-CID (a) and IRMPD (b); selected ion chromatogram of $m / z 167$ by SORI-CID (c) and IRMPD (d); selected ion chromatogram of $m / z 205$ by SORI-CID (e) and IRMPD (f); selected ion chromatogram of $m / z 85$ by SORI-CID (g) and IRMPD (h); selected ion chromatogram of $\mathrm{m} / \mathrm{z} 197$ by SORI-CID (i) and IRMPD (j); selected ion chromatogram of $m / z 157$ by SORI-CID (k) and IRMPD (1); selected ion chromatogram of $m / z 139$ by SORI-CID (m) and IRMPD (n); selected ion chromatogram of $\mathrm{m} / \mathrm{z} 207$ by SORI-CID (o) and IRMPD (p). Note: The indicated times were detection times (retention time $=$ detection time $+25 \mathrm{~min}$ ). 
197,157, 13,9 and 207 (Figure 6i, k, m, o, and j, 1, n, p) with identical detection times (9.64 min), suggesting that they were from 11,12,15-THETA (see also Figure $4 a, b, c$, and d). The $m / z 205$ also exhibited a small peak at a longer detection time (10.60 $\mathrm{min})$. This ion is present in the spectra of both $11,14,15$ - and $13,14,15-$ THETA. However, the peak of the biological sample at $10.60 \mathrm{~min}$ did not have $\mathrm{m} / \mathrm{z} 193$ and the retention time did not match 13,14,15-THETA, suggesting the possibility of another THETA being present at very low concentration.

To further confirm the identity of these THETAs, a mixture of 11,12,15-THETA and 11,14,15-THETA was analyzed by LC-FTICR using the same conditions as the biological sample. The retention times and MS/MS spectra of biological THETAs were identical to the THETA standards. Comparing to the abundance of THETA standards, the concentration of THETAs in biological samples was $\sim 800 \mathrm{pg}$ on the column. The results indicated that both $11,12,15$ - and $11,14,15$ THETA were produced in the rabbit aorta with 11,14,15-THETA being the major isomer.

\section{Conclusions}

Many isomers of low molecular weight, biologically active compounds such as eicosanoids can be present in biological samples. LC-MS and LC-MS/MS have been very successful in the identification and determination of eicosanoids with less complex molecular structures such as HETEs and DHETs. However, relatively newer groups of eicosanoids such as THETAs, which contain more hydroxyl groups at various positions on the arachidonic acid backbone, are more challenging. Chromatographic separation, particularly with reverse phase, of these compounds is difficult. Furthermore, the MS/MS fragmentation patterns of these compounds are very complex and not always useful for stereochemical identification.

Previously, eicosanoids were successfully identified by GC-MS. The substituents on the eicosanoids such as hydroxyl groups were typically derivatized to improve sample volatility. With increasing hydroxyl groups, the efficiency of chemical derivatization decreased. Thus, if LC-MS can accomplish the identification without the need for derivatization, it will be a powerful tool for these compounds. The SORI-CID and IRMPD in FTICR provide unique and useful spectral characteristics of highly substituted eicosanoids such as THETAs. Taking advantages of FTICR for its high mass resolution and accuracy, their fragments and molecular structures can be assigned. As demonstrated here, the regioisomers of the unresolved mixture of THETAs in biological samples were identified.

\section{Acknowledgments}

The authors acknowledge that this equipment was made possible by the generosity of the Kern Family Foundation, the Walter
Schroeder Foundation, the Stackner Family Foundation, Associated Bank, the Raymond and the Bernice Eschenburg Fund of the Greater Milwaukee Foundation, and an anonymous donor. They acknowledge that the upgrades of the FTICR system were supported by Advancing a Healthier Wisconsin Research and Education Funding. They also acknowledge that these studies were supported by grants from the National Institute of Health (HL37,981 and GM-31,278) and the Robert A. Welch Foundation.

\section{References}

1. Laude, D. A. Electrospray Ionization/Fourier Transform Ion Cyclotron Resonance Mass Spectrometry. Electrospray Ionization Mass Spectrometry: Fundamentals, Instrumentation, and Applications; John Wiley and Sons, Inc.: New York, 1997; pp 291-320.

2. Flora, J. W.; Muddiman, D. C. Determination of the Relative Energies of Activation for the Dissociation of Aromatic Versus Aliphatic Phosphopeptides by ESI-FTICR-MS and IRMPD. J. Am. Soc. Mass Spectrom. 2004, 15, 121-127.

3. Johnson, K. L.; Ovsyannikova, I. G.; Madden, B. J.; Poland, G. A.; Muddiman, D. C. Accurate Mass Precursor Ion Data and Tandem Mass Spectrometry Identify a Class I Human Leukocyte Antigen A*0201Presented Peptide Originating from Vaccinia Virus. J. Am. Soc. Mass Spectrom. 2005, 16, 1812-1817.

4. Park, Y.; Lebrilla, C. B. Application of Fourier Transform Ion Cyclotron Resonance Mass Spectrometry to Oligosaccharides. Mass Spectrom. Rev. 2005, 24, 232-264.

5. Pasa-Tolic, L.; Masselon, C.; Barry, R. C.; Shen, Y.; Smith, R. D. Proteomic Analyses Using an Accurate Mass and Time Tag Strategy. Biotechniques 2004, 37, 621-636.

6. Page, J. S.; Masselon, C. D.; Smith, R. D. FTICR Mass Spectrometry for Qualitative and Quantitative Bioanalyses. Curr. Opin. Biotechnol. 2004, 15, 3-11.

7. Reinhold, S. W.; Vitzthum, H.; Filbeck, T.; Wolf, K.; Lattas, C.; Riegger, G. A.; Kurtz, A.; Kramer, B. K. Gene Expression of 5-, 12-, and 15-Lipoxygenases and Leukotriene Receptors Along the Rat Nephron. Am. I. Physiol. Renal Physiol. 2006, 290, F864-872

8. Newby, C. S.; Mallet, A. I. Rapid Simultaneous Analysis of Prostaglandin E2, 12-Hydroxyeicosatetraenoic Acid, and Arachidonic Acid Using High Performance Liquid Chromatography/Electrospray Ionization Mass Spectrometry. Rapid Commun. Mass Spectrom. 1997, 11, 1723-1727.

9. Nithipatikom, K.; Isbell, M. A.; See, W. A.; Campbell, W. B. Elevated 12 and 20-Hydroxyeicosatetraenoic Acid in Urine of Patients with Prostatic Diseases. Cancer Lett. 2005, 233, 219-225.

10. Fretland, D. J.; Anglin, C. P.; Bremer, M.; Isakson, P.; Widomski, D. L.; Paulson, S. K.; Docter, S. H.; Djuric, S. W.; Penning, T. D.; Yu, S.; McKearn, J. P. Anti-inflammatory Effects of Second-Generation Leukotriene B4 Receptor Antagonist, SC-53228: Impact Upon leukotriene B4and 12(R)-HETE-Mediated Events. Inflammation 1995, 19, 193-205.

11. Suzuki, N.; Hishinuma, T.; Saga, T.; Sato, J.; Toyota, T.; Goto, J.; Mizugaki, M. Determination of Urinary 12(S)-Hydroxyeicosatetraenoic Acid by Liquid Chromatography-Tandem Mass Spectrometry with Column-Switching Technique: Sex Difference in Healthy Volunteers and Patients with Diabetes mellitus. J. Chromatogr. B Analyt. Technol. Biomed. Life Sci. 2003, 783, 383-389.

12. Vanderhoek, J. Y. Role of the 15-Lipoxygenase in the Immune System. Ann. N.Y. Acad. Sci. 1988, 524, 240-251.

13. Ternowitz, T.; Fogh, K.; Kragballe, K. 15-Hydroxyeicosatetraenoic acid (15-HETE) Specifically Inhibits LTB4-Induced Chemotaxis of Human Neutrophils. Skin Pharmacol. 1988, 1, 93-99.

14. Grimminger, F.; Mayser, P. Lipid Mediators, Free Fatty Acids, and Psoriasis. Prostaglandins Leukot. Essent. Fatty Acids 1995, 52, 1-15.

15. Capdevila, J. H.; Falck, J. R.; Harris, R. C. Cytochrome P450 and Arachidonic Acid Bioactivation. Molecular and Functional Properties of the Arachidonate Mono-oxygenase. J. Lipid Res. 2000, 41, 163-181.

16. Fang, X.; Kaduce, T. L.; Weintraub, N. L.; Harmon, S.; Teesch, L. M. Morisseau, C.; Thompson, D. A.; Hammock, B. D.; Spector, A. A Pathways of Epoxyeicosatrienoic Acid Metabolism in endothelial cells. Implications for the Vascular Effects of Soluble Epoxide Hydrolase Inhibition. J. Biol. Chem. 2001, 276, 14867-14874.

17. Fang, X.; Weintraub, N. L.; McCaw, R. B.; Hu, S.; Harmon, S. D. Rice J. B.; Hammock, B. D.; Spector, A. A. Effect of Soluble Epoxide Hydrolase Inhibition on Epoxyeicosatrienoic Acid Metabolism in Human Blood Vessels. Am. J Physiol. Heart Circ. Physiol. 2004, 287, H24122420.

18. Hirt, D. L.; Capdevila, J.; Falck, J. R.; Breyer, M. D.; Jacobson, H. R. Cytochrome P450 Metabolites of Arachidonic Acid are Potent Inhibitors of Vasopressin Action on Rabbit Cortical Collecting duct. J. Clin. Invest. 1989, 84, 1805-1812.

19. Fang, X.; Moore, S. A.; Stoll, L. L.; Rich, G.; Kaduce, T. L.; Weintraub N. L.; Spector, A. A. 14,15-Epoxyeicosatrienoic Acid Inhibits Prostaglandin E2 Production in Vascular Smooth Muscle Cells. Am. J. Physiol. 1998 275, H2113-2121.

20. Campbell, W. B.; Gebremedhin, D.; Pratt, P. F.; Harder, D. R. Identification of Epoxyeicosatrienoic Acids as Endothelium-Derived Hyperpolarizing Factors. Circ. Res. 1996, 78, 415-423. 
21. Campbell, W. B.; Deeter, C.; Gauthier, K. M.; Ingraham, R. H.; Falck, J. R.: Li, P. L 14,15-Dihydroxyeicosatrienoic Acid Relaxes Bovine Coronary Arteries by Activation of K(Ca) Channels. Am. J. Physiol. Heart Circ. Physiol. 2002, 282, H1656-1664.

22. Li, P. L.; Campbell, W. B. Epoxyeicosatrienoic Acids Activate K+ Channels in Coronary Smooth Muscle Through a Guanine Nucleotide Binding Protein. Circ. Res. 1997, 80, 877-884.

23. Oltman, C. L.; Weintraub, N. L.; VanRollins, M.; Dellsperger, K. C. Epoxyeicosatrienoic Acids and Dihydroxyeicosatrienoic Acids are Potent Vasodilators in the Canine Coronary Microcirculation. Circ. Res. $1998,83,932-939$

24. Li, P. L.; Chen, C. L.; Bortell, R.; Campbell, W. B. 11,12-Epoxyeicosatrienoic Acid Stimulates Endogenous Mono-ADP-Ribosylation in Bovine Coronary Arterial Smooth Muscle. Circ. Res. 1999, 85, 349-356.

25. Fisslthaler, B.; Popp, R.; Kiss, L.; Potente, M.; Harder, D. R.; Fleming, I.; Busse, R. Cytochrome P450 2C is an EDHF Synthase in Coronary Arteries. Nature 1999, 401, 493-497.

26. Fang, X.; Hu, S.; Xu, B.; Snyder, G. D.; Harmon, S.; Yao, J.; Liu, Y.; Sangras, B.; Falck, J. R.; Weintraub, N. L.; Spector, A. A. 14,15-Dihydroxyeicosatrienoic Acid Activates Peroxisome Proliferator-Activated Receptor- $\alpha$. Am. J. Physiol. Heart Circ. Physiol. 2006, 290, H55-63.

27. Pfister, S. L.; Spitzbarth, N.; Edgemond, W.; Campbell, W. B. Vasorelaxation by an Endothelium-Derived Metabolite of Arachidonic Acid. Am. J. Physiol. 1996, 270, H1021-1030.

28. Pfister, S. L.; Spitzbarth, N.; Nithipatikom, K.; Edgemond, W. S.; Falck, J. R.; Campbell, W. B. Identification of the 11,14,15- and 11,12, 15Trihydroxyeicosatrienoic Acids as Endothelium-Derived Relaxing Factors of Rabbit Aorta. J. Biol. Chem. 1998, 273, 30879-30887.

29. Campbell, W. B.; Spitzbarth, N.; Gauthier, K. M.; Pfister, S. L. 11,12,15Trihydroxyeicosatrienoic Acid Mediates ACh-Induced Relaxations in Rabbit Aorta. Am. J. Physiol. Heart Circ. Physiol. 2003, 285, H2648-2656.

30. Gauthier, K. M.; Spitzbarth, N.; Edwards, E. M.; Campbell, W. B. Apamin-Sensitive K+ Currents Mediate Arachidonic Acid-Induced Relaxations of Rabbit Aorta. Hypertension 2004, 43, 413-419.

31. Zhang, D. X.; Gauthier, K. M.; Chawengsub, Y.; Holmes, B. B.; Campbell, W. B. Cyclo-oxygenase- and Lipoxygenase-Dependent Relaxation to Arachidonic Acid in Rabbit Small Mesenteric Arteries. Am. J. Physiol. Heart Circ. Physiol. 2005, 288, H302-309.

32. Kerwin, J. L.; Torvik, J. J. Identification of Monohydroxy Fatty Acids by Electrospray Mass Spectrometry and Tandem Mass Spectrometry. Anal. Biochem. 1996, 237, 56-64.
33. Nakamura, T.; Bratton, D. L.; Murphy, R. C. Analysis of Epoxyeicosatrienoic and Monohydroxyeicosatetraenoic Acids Esterified to Phospholipids in Human Red Blood Cells by Electrospray Tandem Mass Spectrometry. J. Mass Spectrom. 1997, 32, 888-896.

34. Nakamura, T.; Henson, P. M.; Murphy, R. C. Occurrence of Oxidized Metabolites of Arachidonic Acid Esterified to Phospholipids in Murine Lung Tissue. Anal. Biochem. 1998, 262, 23-32.

35. Sun, D.; McDonnell, M.; Chen, X. S.; Lakkis, M. M.; Li, H.; Isaacs, S. N.; Elsea, S. H.; Patel, P. I.; Funk, C. D. Human 12(R)-Lipoxygenase and the Mouse Ortholog. Molecular Cloning, Expression, and Gene Chromosomal Assignment. J. Biol. Chem. 1998, 273, 33540-33547.

36. Wheelan, P.; Zirrolli, J. A.; Murphy, R. C. Low-Energy Fast Atom Bombardment Tandem Mass Spectrometry of Monohydroxy Substituted Unsaturated Fatty Acids. Biol. Mass Spectrom. 1993, 22, 465-473.

37. Nithipatikom, K.; DiCamelli, R. F.; Kohler, S.; Gumina, R. J.; Falck, J. R.; Campbell, W. B.; Gross, G. J. Determination of Cytochrome P450 Metabolites of Arachidonic Acid in Coronary Venous Plasma During Ischemia and Reperfusion in Dogs. Anal. Biochem. 2001, 292, 115-124.

38. MacPherson, J. C.; Pavlovich, J. G.; Jacobs, R. S. Biosynthesis of Arachidonic Acid Metabolites in Limulus polyphemus Amebocytes: Analysis by Liquid Chromatography-Electrospray Ionization Mass Spectrometry. Biochim. Biophys. Acta 1996, 1303, 127-136.

39. Bylund, J.; Ericsson, J.; Oliw, E. H. Analysis of Cytochrome P450 Metabolites of Arachidonic and Linoleic Acids by Liquid Chromatography-Mass Spectrometry with Ion Trap MS. Anal. Biochem. 1998, 265, 55-68.

40. Zhang, J. H.; Pearson, T.; Matharoo-Ball, B.; Ortori, C. A.; Warren, A. Y.; Khan, R.; Barrett, D. A. Quantitative Profiling of Epoxyeicosatrienoic, Hydroxyeicosatetraenoic, and Dihydroxyeicosatetraenoic Acids in $\mathrm{Hu}-$ man Intrauterine Tissues Using Liquid Chromatography-Electrospray Ionization Tandem Mass Spectrometry. Anal. Biochem. 2007, 365, 40-51.

41. Murphy, R. C.; Barkley, R. M.; Zemski Berry, K.; Hankin, J.; Harrison K.; Johnson, C.; Krank, J.; McAnoy, A.; Uhlson, C.; Zarini, S. Electrospray Ionization and Tandem Mass Spectrometry of Eicosanoids. Anal. Biochem. 2005, 346, 1-42.

42. Falck, J. R.; Barma, D. K.; Mohapatra, S.; Bandyopadhyay, A.; Reddy, K. M.; Qi, J.; Campbell, W. B. Asymmetric Synthesis of the Stereoisomers of 11,12,15(S)-Trihydroxyeicosa-5(Z),8(Z),13(E)-Trienoic Acid, a Potent Endothelium-Derived Vasodilator. Bioorg. Med. Chem. Lett. 2004, 14, 4987-4990. 